Florida International University FIU Digital Commons

$3-28-2012$

\title{
The Effectiveness of Nongovernmental Organizations and their Impact on the Status of Women in Nicaragua
}

Monica Weeks

Florida International University, monica.s.weeks@gmail.com

DOI: $10.25148 /$ etd.FI12050221

Follow this and additional works at: https://digitalcommons.fiu.edu/etd

\section{Recommended Citation}

Weeks, Monica, "The Effectiveness of Nongovernmental Organizations and their Impact on the Status of Women in Nicaragua" (2012). FIU Electronic Theses and Dissertations. 615.

https://digitalcommons.fiu.edu/etd/615 


\title{
FLORIDA INTERNATIONAL UNIVERSITY
}

Miami, FL

\section{THE EFFECTIVENESS OF NONGOVERNMENTAL ORGANIZATIONS AND THEIR IMPACT ON THE STATUS OF WOMEN IN NICARAGUA}

\author{
A thesis submitted in partial fulfillment of the requirements for the degree of \\ MASTER OF ARTS \\ in \\ LATIN AMERICAN AND CARIBBEAN STUDIES \\ by \\ Monica S. Weeks
}

2012 


\section{To: Dean Kenneth Furton}

College of Arts and Sciences

This thesis, written by Monica S. Weeks, and entitled The Effectiveness of Nongovernmental Organizations and their Impact on the Status of Women in Nicaragua, having been approved in respect to style and intellectual content, in referred to you for judgment.

We have read this thesis and recommend that it be approved.

Ana Marie Bidegain

Mark Szuchman

Clair Apodaca

Date of Defense: March 28, 2012

The thesis of Monica S. Weeks is approved.

Dean Kenneth Furton

College of Arts and Sciences

Dean Lakshmi N. Reddi

University Graduate School

Florida International University, 2012 
(C) Copyright 2012 by Monica S. Weeks

All rights reserved. 


\section{DEDICATION}

I dedicate this thesis to all women. 


\section{ACKNOWLEDGMENTS}

I would like to thank the Tinker Foundation for awarding me the Tinker Field Research Grant to conduct research in Managua, Nicaragua. The grant allowed me to conduct personal interviews, and I will forever be thankful for this eye-opening and thoughtprovoking experience.

I am forever indebted to my thesis chair, Dr. Clair Apodaca. Thank you for your honesty, assistance, constant revisions, and for responding to my emails so quickly. In addition, I have to thank my committee members, Dr. Mark Szuchman and Dr. Ana Maria Bidegain.

Dr. Szuchman, thank you for your encouragement, suggestions, wit, and for providing much needed historical perspective. Dr. Bidegain, thank you for your kindness, unconditional support, and amazing references and suggestions. Thank you all for contributing to a study that I am truly proud of; I am eternally grateful.

My supportive and kind partner, Ross Templeton, deserves a multitude of thanks. His unconditional love and patience guided me throughout the entire process. His endless corrections and revisions made me a much better writer and for all of the above, I thank you forever.

To the Latin American and Caribbean Studies Center and all of those who supported me during this process including my peers, professors, friends, and family, I thank you for all of your support and encouragement.

Lastly, thank you to the women who allowed me a glimpse into their lives and the work they are performing every day. You are an inspiration. 


\title{
ABSTRACT OF THE THESIS \\ THE EFFECTIVENESS OF NONGOVERNMENTAL ORGANIZATIONS IN NICARAGUA AND THEIR AFFECT ON THE STATUS OF WOMEN
}

\author{
by \\ Monica S. Weeks \\ Florida International University, 2012 \\ Miami, Florida \\ Professor Clair Apodaca, Major Professor
}

The purpose of this study was to identify the role of nongovernmental organizations in Nicaragua and their impact on the status of women. The study analyzed the status of women at the beginning of the revolution, starting in 1980 . The study then examined the evolution of non-governmental organizations deriving from the original group named the Luisa Amanda Espinosa Association of Nicaraguan Women (AMNLAE). It then described the impact of non-governmental organizations on policy making and building civic societies. Ultimately, this study analyzed the status of women thirty years after the revolution and demonstrates through institutionalism that because of the effect of non-governmental organizations on society, the status of women has improved. It then concluded that nongovernmental and intergovernmental organizations are necessary for building civic societies wherein gender equality is accepted. 


\section{TABLE OF CONTENTS}

CHAPTER

PAGE

CHAPTER I: BACKGROUND

Introduction

Significance of Study

Definitions

Brief Historical Background of Nicaraguan Revolution

The Role Women Played in Nicaraguan Revolution

Evolution of Women's Nongovernmental Organizations

The Catholic Church's Role in Revolution

The Catholic Church and the Role of Women

Research Questions

Chapter Summary

CHAPTER II: LITERATURE REVIEW

Introduction

Early Women's Movement

Catholic Church's Role during Revolution

Church's Role in Women's Movement after 1979 Revolution 21

1979 Revolution and Women's Movement

Birth of the Women's Movement from 1979 Revolution

Shortcomings of Revolution and AMNLAE

Impact of Women's Movement on the Status of Women 25

Economy and its Impact of Women's Movement 26

How Gender has developed through Social Movements $\quad 27$

Transnational Processes and Impact on NGOs 28

Theoretical Perspective $\quad 33$

Chapter Summary $\quad 35$

CHAPTER III: METHODS

Introduction $\quad 36$

Part I: United Nations Development Programme: HDI 37

$\begin{array}{ll}\text { Human Development Index } & 37\end{array}$

Part II: Interview Process $\quad 39$

$\begin{array}{ll}\text { Preparing for Interview } & 40\end{array}$

Interview Collection $\quad 40$

Sample Size $\quad 46$

Part III: Survey Collection $\quad 48$

$\begin{array}{lr}\text { Hypothesis } & 50\end{array}$

Chapter Summary 
CHAPTER IV: FINDINGS

Introduction

From Women's Movement to Women's Organizations 54

Autonomy for the Women's Movement after AMNLAE 55

Impact of AMNLAE and NGOs on policy making in 1980s 57

$\begin{array}{ll}\text { Impact of NGOs from 1990s-Present } & 62\end{array}$

International Attention for Women's Movement 65

Traditional Elements Push back against Advancement of Women 68

$\begin{array}{ll}\text { Catholic Church } & 68\end{array}$

$\begin{array}{ll}\text { The Election of } 1990 & 69\end{array}$

Violeta Chamorro and the Feminist Movement $\quad 71$

$\begin{array}{ll}\text { Violeta Chamorro's Neoliberal Reforms } & 72\end{array}$

$\begin{array}{ll}\text { Machismo } & 74\end{array}$

Domestic Violence $\quad 76$

Status of Women in 1980 at the Beginning of the Revolution 79

Status of Women from 1990s-2000s $\quad 80$

Status of Women: An Overview $\quad 81$

$\begin{array}{ll}\text { Chapter Summary } & 84\end{array}$

CHAPTER V: CONCLUSION

REFERENCES 95 


\section{CHAPTER I: BACKGROUND}

\section{Introduction}

The Nicaraguan Revolution in 1979 provided a platform for women to develop their own women's rights organizations and to gain political leverage. Since that time, women's nongovernmental organizations (NGOs) have made significant strides for women's rights. My study will provide a brief historical perspective of how the revolution inspired the women's movement which led to the implementation of state policies and the creation of nongovernmental organizations. Through the actions of nongovernmental organizations, Nicaraguan women have been able to participate in policy making, earn equal pay, and fight for their families and individual rights. Although NGOs have been instrumental in assisting Nicaraguan women in their fight for gaining political leverage, it is still unclear how and to what extent they have helped women in their struggle. The problem to be examined is whether NGOs have made an impact empowering women.

After the formation of the Sandinista Front for National Liberation (FSLN), women were offered platforms from which to voice their concerns. However, as women began to question their place in society and voice their concerns, they noticed the FSLN was hesitant to make women's need a priority. Thus, women demanded that their opinions and needs be taken into consideration. Women advocated for equal treatment for political prisoners, the mothers of political prisoners, rural and urban women, the upperclass elites, and all sectors of society. They not only voiced their concerns, but worked through them and for them. Women formed organizations, initiated reforms in policy, 
and helped change the way men think about women in Nicaraguan society (Disney, 2008). Through the use of non-governmental organizations, women were able to form their own ideas and were extremely vocal in doing so. The legacy of their work is still present today, and it is truly inspiring to observe and study what they have accomplished.

\section{Significance of Study}

This study is significant for three reasons. First, this study can justify further allocation of resources to effective nongovernmental organizations. Nongovernmental organizations have contributed to social movements that have encouraged democratic transition from military regimes that ruled Latin America (Foweraker, 2001). Nongovernmental organizations have also sought to find solutions to the economic crisis that led to a rise in poverty. Although national and international policy makers agree that NGOs have assisted tremendously in the promotion of democracy and civic rebuilding in Nicaragua, NGOs are still struggling for financial and social resources (Gordon, 2007). The present study hopes to shed light on the possible contributions NGOs are making in Nicaragua so that they are able to gain more political and financial resources.

Secondly, there have been few studies conducted on the relationship between NGOs and the Nicaraguan state and very few of these studies have focused on the women's movement. Most of the studies conducted in Nicaragua have not gained much attention in national and international arenas. My study strives to add to the growing amount of research performed in Nicaragua and to demonstrate the effectiveness of NGOs in order for these organizations to continue to gain political leverage. This 
research will contribute to our knowledge to the overlooked topic of post-revolutionary Nicaragua, which has been neglected in disciplines such as history and political science.

Finally, this study also strives to promote Nicaragua's women's movement so that it is an example to other women's movements across the globe. Karen Kampwirth's book, Feminism and the Legacy of Revolution: Nicaragua, El Salvador, Chiapas, states that Latin American feminists are "born of revolutions" and differ from North American or European feminists in that they strive to promote social changes (2004: ). Mostly, Latin American feminists are concerned with politics more than theory. Latin American feminist literature explores how the Nicaraguan women's movement can provide examples on how to incorporate more political practice than theory.

\section{Definitions}

The following definitions were adopted so that the reader is able to understand precisely the denotation that is conveyed within the text for the present study. These definitions were gathered from various sources. The first definition to be discussed is feminism. According to authors Victoria Gonzalez and Karen Kampwirth, "a single definition of feminism is elusive: meanings shifted over the course of the twentieth century and from country to country" (2001: 11). However the authors demonstrate that Latin American feminists, specifically, fight for social reforms in order to construct an enriched society which, "might be constructed by enfranchising women and through reforms such as protecting working mothers and abolishing prostitution and alcoholism" (2001:12). Nathalie Lebon and Elizabeth Maier define Latin American feminists as "feministas: in favor of autonomous feminist organizing without allegiance to party 
politics" (2010:8). Gonzalez and Kampwirth point out that the first-wave Latin American feminists tended to be middle-class and well-educated. These first-wave feminists often did not "concern themselves with improving the lives of poor and working-class; women tended to adopt paternalistic attitudes" (2001:13). However, a second wave of feminism rose in the 1960s heralding in a new set of characteristics and demands. The second wave feminism grew out of the "new left" which was based on egalitarian views and "a commitment to promote that world through organized protest" (2001:13). Second wave feminists still struggled against class barriers and inequality issues and added reproduction rights as a part of their agenda. Second-wave feminism incorporated all sectors of society including the lower class as well.

Non-governmental organizations (NGOs) are sometimes broadly and incorrectly defined and understood. For the purposes of this paper, nongovernmental organizations will refer to locally-based Nicaraguan organizations in Managua. Laura Macdonald provides further explanation of what NGOs are and their roles in society. According to Macdonald:

For decades, NGOs were perceived as peripheral actors, providing humanitarian assistance and organizing small, grassroots development projects on the margins of Third World Society. Recently, however, NGOs themselves, as well as their observers, have begun to focus on their role in supporting civic society (1997:3).

Macdonald further explains that civic society "constitutes the arena of organized political activity between the private sphere (the household and the firm) and the formal political institutions of governance (the parliament, political parties, the army, etc.)" (1997:3). Macdonald provides an precise definition of NGOs in her text, $\underline{\text { Supporting }}$

\section{Civic Society:}


National NGOs: These are non-profit organizations based in the South, whose principle function is to implement development projects favoring the popular sectors. National NGOs' main sources of financial support are international NGOs, but they may also receive support from Northern governments and or international organizations. Both national and international NGOs are usually made up of middle-class professionals who provide technical support, training and financial support to communities. National NGOs serve as intermediaries between beneficiaries and government, international NGOs and financial institutions (1997:7).

Thus, NGOs may be a part of a grassroots movement or self-help movement.

Grassroots movements tend to, "represent groups long disenfranchised" and are an "emerging part of civic society, and that is the foundation of a democracy that goes beyond occasional elections" (1997:6). New social movements (NSM) are comparable to grassroots movements. However, grassroots movements tend to be focused on class politics. According to Stephanie Linkogle, "NSMs have been characterized as dynamic, 'democratized' organizations that operate outside the parameters of an exclusively classbased politics" (1996:112). The literature written about grassroots movement has developed to differentiate between "new" movements and "older" movements.

\section{Brief historical background of the Nicaraguan Revolution}

In the early 1900s, President Jose Santos Zelaya assumed the presidency in

Nicaragua. He opposed the idea of the Americans to build a canal that would be exclusive to only Americans and that would include a piece of Nicaraguan territory. Tensions grew and with the help of the monetary assistance of the United Fruit Company, the United States succeeded in removing Zelaya and installing Adolfo Diaz. As President, Diaz, however, could not retain control of Nicaragua. Consequently, the United States Marines occupied Nicaragua from 1912-1926. Meanwhile, a Nicaraguan nationalist named 
Augusto Calderon Sandino led guerilla wars against American imperialism. Sandino was assassinated in 1934 by the National Guard led by Anastasio Somoza.

Somoza had been in charge of the National Guard when the Marines recognized his leadership qualities and loyalty to the United States. Somoza became a servant to the United States and designed his economic policies around his personal gains, such as depositing monies from welfare programs for Nicaragua into his personal bank account (Landau, 1993). Somoza's reign, and that of his sons, referred to as the Somoza Dynasty, was corrupt and gleaned wealth from all sectors of society. Somoza did not finance welfare programs, healthcare, or education nor did he have the support of the people (Foweraker, 1993). Subsequently, Anastasio Senior was murdered in 1956 and Anastasio Junior assumed the role of President.

In 1961, a group of revolutionaries who drew inspiration from the Cuban Revolution, combining Latin American nationalism and Marxist ideology, instigated guerilla warfare against the Somoza regime after forming the Sandinista Front for National Liberation (FSLN) (Landau, 1993). The FSLN took the name of Augusto Sandino to evoke earlier revolutionary struggles (Landau, 1993). The FSLN had grown tired of the US occupation and the avaricious Somoza regime. The FSLN saw the Cuban Revolution as the paradigm to achieve a just society (Landau, 1993). At first, their struggles appeared futile. However, in 1972 an earthquake struck Nicaragua. Somoza took advantage of the aid pouring in from all over the world, and this demonstrated his true character to many former supporters who had overlooked his transgressions against Nicaragua and Nicaraguans (BBC, 2005). 
The FSLN grew quickly throughout the worker and peasant communities as well as the Christian communities. As the FSLN grew, so did the violence from the Somoza regime. The National Guard performed the worse kinds of human rights atrocities including, rape, torture, and murder. However, the Nicaraguan people and the FSLN persevered and on July 17, 1979, the Somoza family fled to Miami, Florida (Landau, 1993). The National Guard fell apart and the FSLN took control of Nicaragua on July 19, 1979.

However, their victory was short-lived. The United States had elected a new president, Ronald Reagan, a conservative who decided to smear the FSLN as "bandits and revolutionaries, liars and aggressors" (Landau, 1993:37). The counterrevolutionary war, or Contra as it became known, began with the formation of the $15^{\text {th }}$ of September Legion. The Contra War consisted of several groups, the main one referred to as the Nicaraguan Democratic Force (FDN), which was composed of former National Guardsmen. As the fighting continued, other sections of Nicaraguan society suffered. The government was consumed with constant war and neglected the health and education systems as well as social programs. Forty-five thousand Nicaraguans had died fighting against Somoza (Colburn, 1991). Resources became scarce and resentment grew. After years of fighting, the Sandinistas lost the 1990 elections to the opposition. Many combatants on both sides of the war were relieved because this meant that they no longer had to keep fighting. They had grown weary and desperate.

However, US intervention continued into the 1990s. Despite the official cessation of hostilities, former Sandinistas and Contras kept fighting, as well as the lower class and 
the old elite against one another (Landau, 1993). Interventionism by the United States never ceased and this became a lesson to all of Latin America.

\section{The Role Women played in the Nicaraguan Revolution}

Several years before the revolution in 1979, mothers and wives would visit political prisoners and bring them food and monitor how prisoners were being treated by their jailers (Bayard de Volo, 2001). Indirect participation and assistance with the prisoners invoked a desire in the mothers and wives who would visit to become further involved in the revolution. Women's involvement in the war spurred the need for a revolutionary party for women. Two attempts were made with, "the aim of encouraging the participation of women workers and campesinas in the political struggle" (Bayard de Volo, 2001:23). The first party was the Organization of Democratic Nicaraguan Women (OMDN) in 1962 organized by the Socialist Party. The second party was called the Patriotic Alliance of Nicaraguan Women (APMN) and was created in 1969 by the FSLN. However, these parties crumbled due to the lack of participation.

In 1969, the FSLN recruited women into the guerilla ranks with the intention to, "abolish the odious discrimination that women have been subjected to compared to men" (Bayard de Volo, 2001:5). After the collapse of the Somoza regime in 1979, women comprised 25 to 30 percent of the combatants. Many of these women had led troops into battle (Bayard de Volo, 2001:5). The women who did not actively participate in the fighting offered their homes to guerillas as safe houses and provided them with food, clothes, medical care, information and hiding places (Staten, 2010). Women also organized shipments of food, medicine, ammunition and guns and even assisted with the 
construction of bombs (Staten, 2010). Most women who had direct contact with the FSLN leaders believed that these men truly believed in the equal rights of women within the revolutionary movement. Nevertheless, women were largely absent from political decision making positions. Feminism was not prevalent during the Sandinista period. However, the Sandinistas were able to improve the education and health benefits of women as well as allow them to mobilize politically (Collinson, 1990).

Women also had no voice in the workplace prior to the revolution. Equal pay was supposed to be a right afforded to women prior to the revolution, but this was ignored by employers (Collinson, 1990). On many occasions, women were denied equal pay because of their sex, maternity leave, or because they would have to tend to their families which required time outside of the workplace. Union representation was weak in some areas and the lack of union representation affected a woman's pay as well as maternity leave and holidays (Collinson, 1990).

Women suffered at home as well. Violence against women was a serious problem that was never openly discussed in Nicaraguan society. According to Helen Collinson, "Under the Somocista system, women were particularly vulnerable to sexual abuse" (1990:19). Gays and lesbians were largely ignored or condemned. Half the population was illiterate and the infant mortality was 130 per 1,000 live births (Jayko, 1982). Women living in urban areas had to raise families on their own because the majority of men were employed in the agricultural sector (Collinson, 1990). Somocista landowners required seasonal migrant workers to move around in order to maintain a cash-crop economy. According to psychologist Vilam Castillo, many men would acquire a seasonal 
migrant job, stay there for four months, impregnate a woman, move, and then impregnate a different woman in a another part of the country (Collinson, 1990:9). According to Helen Collinson, this led to the "lack of a stable monogamous family life" (1990: 9).

Although the Sandinistas provided many more opportunities to women than women had during the Somoza regime, women were still not offered the same opportunities as men by the ruling junta. Many authors and scholars attribute the lack of equality to the prevalence of "machismo" in Nicaraguan society. According to Clifford Staten, machismo is, "tied into the cultural trait of the Latin American male's pursuit of importance, prestige, dignity, honor and status. It has manifested itself nationally in male dominance in areas of politics and economics with women playing the more traditional roles associated with spirituality, motherhood and child rearing” (2010:127).

\section{Evolution of Women's Nongovernmental Organizations}

There had been several attempts to form an organization focused on women's needs in 1962 and 1969. However, it was not until 1977 that the organization was formulated and created. The FSLN along with Father Ernesto Cardenal, "brought together a group of Sandinista and non-Sandinista women to discuss the formation of a women's organization to denounce the Somoza regime" (Bayard de Volo, 2001:25). The group was called the Association of Women Confronting the National Problem (AMPRONAC). There appears to be controversy over who created the group and whether it was autonomous from the Sandinista National Liberation Front. Nonetheless, the group's main goals included the protection of human rights, the overthrow of the Somoza dictatorship, and the mobilization and participation of women in issues of 
national concern (Disney, 2008). In 1979 as AMPRONAC grew, it began to demand more for women's liberation. These demands included: "equality of civil rights and equal pay for equal work, an end to the commercialization of women, a need to combat prostitution" (Collinson, 1990: 140). As a social group, AMPRONAC was extremely successful. From its humble beginnings in 1977 of 60 women, it grew to over 8,000 towards the end of its life in 1979 (Collinson, 1990). According to Helen Collinson, AMPRONAC, “organized demonstrations, circulated petitions, carried messages from political prisoners to their families, and lobbied the government to disclose the whereabouts of the "disappeared"' (1990:140).

After the Sandinistas overthrew Somoza in 1979, the group changed its name to the Luisa Amanda Espinosa Association of Nicaragua Women (AMNLAE) (Disney, 2008). The organization's new name referred to Luisa Amanda Espinosa, the first woman who was killed in the war against Somoza (Disney, 2008). Leaders of AMNLAE strove to reduce use of the term "feminism," and to appeal to a wide variety of interests within the woman's struggle. Feminism, at the time, was seen as anti-male rhetoric sent from the foreigners in the United States who wished to divide men and women in Nicaraguan society (Collinson, 1990). Unfortunately, the AMNLAE lacked ideological and organizational autonomy (Disney, 2008). Although the FSLN may have been an integral part in establishing the AMNLAE, the FSLN utilized women in the struggle to fight and never asked the women what they needed themselves. The FSLN was primarily concerned with the needs of the revolutionary party and its members regardless of their sex. It was the organization's original purpose to incorporate women into general 
revolutionary tasks (Collinson, 1990). As time went on, women began to develop their understanding of the obstacles they faced because of their gender. Such understanding or concern was lost or ignored by the large majority of male membership of the FSLN. Regardless of these obstacles, AMNLAE continued to actively participate in the liberation of women. The AMNLAE's efforts assisted women in gaining confidence and in confronting larger issues.

Unfortunately, according to Helen Collinson, AMNLAE suffered from, "a lack of clear objectives, administrative capacity, and experienced women, the best of whom were working in other areas. Despite subsequent attempts to streamline operations, the problem continued" (1990: 141). It also appears that AMNLAE was being pulled in different directions. Women were expected to be politically active within AMNLAE and then had to return home to fulfill domestic roles. These concerns were never given priority from the Sandinista National Liberation Front. Membership declined for AMNLAE and in 1985, they held 600 local meetings of women to ascertain what women wanted from AMNLAE (Collinson, 1990). According to Helen Collinson, the demands included but were not limited to: "the demand for more information and access to birth control, the issues of sexual harassment at work, of rape and domestic violence, and men's failure to share the domestic burden of childcare and housework" (1990: 143). After many meetings, discussions and lobbying, the FSLN and AMNLAE issued the Proclama in 1987. The Proclama established AMNLAE's priorities, addressed women's struggles within the revolution, and condemned machismo. According to Helen Collinson, 'Most importantly, it argued that women's issues could not be 'put off' till 
after the war" (1990:145). It made it abundantly clear that women's issues were no longer concerns of only women acknowledging that women were instrumental to the development of society. Towards the late 1980s, AMNLAE began to act pragmatically and began to cater to the needs of women (Collinson, 1990). Training centers for women were opened by AMNLAE and they offered sex education, political training courses, as well as domestic training courses (Perkins, 1995). In September 1988, AMNLAE changed its name to the Movement of Nicaraguan Women (Collinson, 1990). The Movement of Nicaraguan Women planned to become more democratic and summoned an electoral process. However, elections were postponed and this demonstrated yet again the lack of cohesion and efficiency present in this organization.

Women who were frustrated with the bureaucratic process of the AMNLAE broke away from the organization and joined others or started their own. One of these organizations includes the Sandinista Federation of Professional Workers (CONAPRO). CONAPRO, which was formed in 1988, is perhaps one of the most progressive organizations in Nicaragua. The group is comprised of doctors, lawyers, and administrators who express their points of view of Nicaraguan society candidly. They are pro-choice and anti-violence. They have utilized radio, pamphlets, conferences, and women's centers to spread their messages and to educate Nicaraguan women.

Another organization called the Committee of Mothers of Heroes and Martyrs of Matagalpa formed in 1979 (Bayard de Volo, 2001). Current organizations that focus on women's rights include Hablemos de Nosotras, La Corriente, and Colectivo de Mujeres. Several other organizations, theater groups, and women's groups drew inspiration from 
AMNLAE and the vast majority of these organizations acknowledges and respects the work of AMNLAE. Nongovernmental organizations recognize the impact AMNLAE has made on Nicaraguan society.

\section{The Catholic Church's Role in the Revolution}

The Roman Catholic Church in Nicaragua played a central role in the revolution. Most Nicaraguans are Roman Catholic and according to Helen Collinson, "the Catholic Church (was) divided between those in the church hierarchy whose aim (was) to preserve a traditional, authoritarian form of religion, and radical sectors outside the hierarchy known as the Church of the Poor, who believed that 'between the Revolution and Christianity there is no contradiction"'(1990: 83). However, it was customary for the Church to align itself with whichever regime was in power in Nicaragua (Collinson, 1990). Although the Church legitimized the Somoza dictatorship, the Church's relationship with the Somoza regime deteriorated in the 1970s as the Church became aware of the regime's growing human rights abuses. Archbishop Obando y Bravo, who was head of the Nicaraguan Church at that time, formed an alliance with the middle-class sector and was determined to create an alternative government from Somoza or the Sandinistas.

In 1979, after the defeat of Somoza, the Church hierarchy aligned themselves with the bourgeoisie and distanced themselves from the FSLN. The Internal Front, known as the political counter-revolutionaries, considered Obando y Bravo their "de facto spokesperson" (Collinson, 1990). Because of the Church's hierarchy aligning itself with the counter-revolutionaries, there have been several conflicts between the Church and the 
Sandinista government. Helen Collinson points out that the Church hierarchy has tried to sway national and international opinion on the Sandinista government by advertising the Church's execution under a “totalitarian Marxist state" (1990:83). Carlos Vilas points out in his book, The Sandinista Revolution, that because of the Church's inability to mediate between the people and Somoza's corrupt regime, many Nicaraguans became disillusioned with the Church (1986:110). He goes on to cite an FSLN document from 1980 which states, "one can be a believer and at the same time a serious revolutionary and that there is no insurmountable contradiction between the two... Many Christians are militants of the FSLN and as long as there are Christian revolutionaries in Nicaragua, there will be Christians within the Frente Sandinista" (Vilas, 1986:224).

\section{The Catholic Church and the Role of Women}

The Catholic Church is an essential organization to analyze in this study because it has had both negative and positive impacts on the status of women. The Catholic Church was an organization that provided a space for women to become politically aware and active. However, this is because of the grassroots level organizers who have been at odds with the Church's hierarchy for several decades. Unfortunately, the conflicts between the Church hierarchy and the grassroots level organizers have led to unclear and often confusing messages to women, especially Christian women. The Church hierarchy has maintained a conservative and politically ambivalent position in Nicaragua in order to maintain its privileged position in the country. On the other hand, the grassroots level churches have often been extremely supportive of women in their quest of political consciousness. 
Particular factions of the Catholic Church in the 1960s who identified themselves as the Church of the Poor, had begun small study groups called Basic Christian Communities (CEBs). The CEBs were considered a part of the new social movement because they were not solely class organizations (Linkogle, 1996). These groups were born in rural and urban areas and were meant for ordinary people to gather and discuss the Bible and how it was relevant to their lives (Collinson, 1990). However, these communities became aware of the struggle against Somoza and began to join forces with the FSLN. According to Helen Collinson, for thousands of women in Central America, "the radical church of the poor (had) been their first contact with politics" (1990:84). The church allowed women the space to develop and share ideas. Women were also able to share problems at home, problems that many women found they had in common, such as husbands with drinking problems. The spaces the Church provided allowed women, especially the urban and rural poor populations, to realize that they had been severely oppressed. However, the CEBs also allowed women the opportunity to examine the positive roles women play in society. Women's roles in church based societies tend to be developed from the role of the Jesus' mother Mary. According to Helen Collinson:

(Mary) provides an idealized picture of virgin and mother-passive, submissive, and asexual, the impression given is that sex is justifiable only in order to become a mother. Motherhood is the central theme defining Nicaraguan women's lives and identities (1990:89).

The Church of the Poor attempted to change this stereotypical view of Mary into a positive role model for Catholic women. Women revolutionaries no longer see Mary as a "sugar, sweet, stupid woman reactionary Christians so often to make her out to be" 
(Collinson, 1990:89). Instead, the Church of the Poor has turned Mary into a liberator of her people.

However, women have continuously been neglected and discriminated against in the church. According to Stephanie Linkogle, "the attitudes and activities of the hierarchical church have effectively constrained women...both in the church and outside of it” (1996:56). Linkogle's text cites Uruguayan historian Ana Maria Bidegain who maintains that feminism was often portrayed as one of the exports of imperialism to be avoided (1996:56). Women were largely responsible for the work done by the CEBs in the community. However, it was the priest, who was much less involved, who legitimized the work of the CEBs to the community's members (Linkogle, 1996). The availability and safety of contraceptives and the right to abortion have been serious contentious issues between the Catholic Church and local women's nongovernmental organizations in Nicaragua (Linkogle, 1996). Prohibitions of pornography, divorce, and issues on domestic violence have been issues that the hierarchical church has maintained opposition to with most women's organizations. The Catholic hierarchy in 1979 pledged its support for, "cultural processes that awaken the dignity of our masses and give them the strength to assume responsibilities and demand their rights" (Foroohar, 1989:201). However, the Church changed its position and accused the Sandinistas of brainwashing their Nicaraguan peoples.

\section{Research Questions}

On the basis of brief history of the women's movement, my study will attempt to answer the following questions: 
Question 1: How and to what extent did the women's movement affect women's NGOs?

Question 2: How and to what extent did the women's movement affect state policies regarding women?

Question 3: How did the women's movement, through the actions of NGOs and the implementation of state policies, affect the status of women?

\section{Chapter Summary}

This chapter provides a brief historical background of the 1979 Nicaraguan Revolution, the role of the Catholic Church in the Revolution, the evolution of the AMNLAE, and the evolution of women's NGOs. This chapter also provides the research questions of which this study will attempt to answer.

In the next section, we observe the literature pertaining to this study. Although the history of the women's movement is brief, there appears to be a sufficient amount of literature written on the subject of nongovernmental organizations and their impact on the status of women, as well as other contiguous topics. In addition, the next chapter provides the theoretical framework for which this study is based. 


\section{CHAPTER II: LITERATURE REVIEW}

\section{Introduction}

In order to prepare for this research, it is important for one to know the breadth and depth of the literature written on this topic. There exists a diverse collection of literature related to the various subjects within this paper. Most of the texts I have chosen to write about can be categorized into the traditional subjects of political science, economics, or women's studies. Most of the methodologies utilized for the majority of these authors were first-hand accounts taken in Nicaragua. However, much of this material does not delve deeply into the impact of NGOs on the status of women. Nonetheless, a significant proportion of scholars agree that the creation of NGOs in Nicaragua has positively affected the status of women.

\section{Early Women's Movement}

Although there was a burst of NGO formation after the revolution, it is important to bear in mind that NGOs existed before the revolution. Victoria Gonzalez and Karen Kampwirth describe the political landscape before the revolution from the 1930s to the 1960s. Although NGOs and a somewhat vibrant feminist movement existed, this generation of feminists faced the same problems as their successors. The early feminist movement suffered from a lack of clear objectives and lack of support from their male comrades. However, according to Victoria Gonzalez, after the failed attempt to win the vote for women, the earlier feminist movement started to fade away and was eventually replaced with a "watered-down Somocista version of 'feminism' and women's rights" 
(2001:51). Karen Kampwirth explains that there is a consensus among feminists and antifeminists that the modern feminist movement started with the Sandinista Revolution in the 1980s (Kampwirth, 2010). However, despite this widespread misconception, Kampwirth traces Nicaraguan feminism back to the early days of the Somoza dictatorship and even to the nineteenth century (Kampwirth, 2010). Yet, the majority of NGOs that exist today were derived from a political revolutionary party. It is crucial to understand when and where the feminist movement originated from because of the lasting impact it has had on organizations and the movement itself.

\section{Catholic Church's Role during Revolution}

Several authors have written about the church's role during the revolution. Authors Andrew Bradstock (1987), Manzar Foroohar (1989), Philip Williams (1989), and John Kirk (1992) describe the church as a controversial actor in Nicaraguan politics especially during the Nicaraguan revolution. Kirk in particular points out that Churchstate relations in Nicaragua were extremely polarized and that within the church, there were several divisions as well (1992:1). The church hierarchy had become accustomed to ignoring Somoza's horrendous human rights violations and, according to Bradstock, the Catholic church was committed to, "defend(ing) the existing order and resisted any change which threatened its own position and influence" (1987:1). However several changes began to occur during the revolution. Father Arias Caldera was the first parish priest to extend his moral and material support to the FSLN and Father Ernesto Cardenal was the first priest who, "attracted the Sandinistas' attention as a potential (political) ally, because of his work in Solentiname" (Foroohar, 1989:117). Bishop Miguel Obando 
y Bravo was the most, "outspoken opponent of the appalling human rights record of the dictatorship" (Kirk, 1992:59). The Bishop served as an intermediary between the FSLN and the government and would often reject invitations from Somoza to attend state functions (Kirk, 1992:59).

After the revolution, the church began to pay more attention to the poorest members of the church at the grassroots level. Foroohar (1989) attributes this to the 1972 earthquake which left several nuns and priests working in the poorest barrios in Managua. The earthquake allowed these religious leaders to experience first-hand the corruption and abuses of international relief funds and materials and they became determined to find the "roots of the problem and ways to deal with it" (Foroohar, 1989:124). The unhappiness with the current social condition led to the local church to begin a long process of an alliance that, "gradually formed between the Marxist and the Christian sectors of the opposition" (Foroohar, 1989:111). Williams cites Christian based communities, CEBs as an integral development from the Catholic Church in an effort for members to "rediscover the spiritual dimension of their faith" (1989:57). However, as a result of the political climate that characterized the revolution, CEBs became less about spaces for "theological reflection" and became more like political activist groups (Williams, 1989:57).

\section{Church's Role in Women's Movement after 1979 Revolution}

The church was an integral actor in the women's rights movement because of its influence on society during the revolution. Stephanie Linkogle (1996) argues that the "institutional construction and reshaping of processes of identification as experienced by 
women participants in the activities of the "popular church"” (1996:3). Linkogle points out that the popular church was opposed to the hierarchical church, and the hierarchical church resisted the popular church's Christian based communities (1996:19). The popular churches applied liberation theology as their principle philosophy and grew in response to the "unmet practical/political and spiritual needs of many oppressed Nicaraguans" (1996:19). Linkogle's text describes the importance of the CEBs and cites these as “democratic and somewhat protected 'bases' from which communities could oppose Somoza' (1996:19). Linkogle (1996) further states that women became increasingly important in running and staffing ollas, communal kitchens formed from Christian Based Communities. Christian Based Communities reemerged in response to the substantial increase in malnutrition resulting from President Violeta Chamorro's harsh neoliberal policies which started in 1990. Linkogle claims that CEBs encouraged its members, mostly comprised of women, to locate the source of their oppression which was referred to as conscientización (1996:57). Christian Based Communities challenged the church, especially the Catholic Church's, “deeply ingrained patriarchy” (Linkogle, 1996:20). Most importantly, CEBs allowed women the space to become politically conscious and active.

\section{Revolution and Women's Movement}

Modern publications about Nicaragua have focused on the impact of the 1979 revolution. These studies have predominantly been concerned with the historical relations between Nicaragua and the United States and how the revolution was conducted from both sides. Many scholars agree that the 1979 revolution did in fact provide the catalyst 
for the women's movement. The revolution helped develop the political consciousness which is an instrumental part of the status of women. Helen Collinson points out that the Sandinista revolution provided "women the space and confidence to start grappling with their oppression" (1990:137). The majority of studies were mostly performed in the mid1980s to the mid-1990s (Landau 1993, Borge 1982, Gobat 2005, Staten 2010, Vilas 1986). Most writers have focused their research from the beginnings of the revolution in 1979 to the 1990s. Authors have described in detail the formation of the revolutionary party, the Sandinista National Liberation Front (FSLN), and more importantly to this thesis, the formation of the women's revolutionary party, the Association of Women Confronting the National Problem (AMPRONAC) in 1977. Author Karen Kampwirth (2002) is worthy of mention because she highlights the ways in which women were involved in the armed struggle, which arguably led to the formation of a political consciousness.

Authors have focused on AMPRONAC and how the organization impacted the status of women. AMPRONAC, later known as the Association of Nicaraguan Women Luisa Amanda Espinosa (AMNLAE), is important because it provided women the experience and understanding of how to efficiently run an organization and it was the revolutionary party that was formed specifically for women and included all women from different sectors of society. However, writers have typically pointed out that AMNLAE lacked autonomy from the FSLN (Collinson 1990, Disney 2000). In addition, researchers point out the frustration and lack of political mobility within the Association of Nicaraguan Women Luisa Amanda Espinosa. Women were allowed to voice their 
concerns and make friendly reforms within the FSLN, but were met with resistance from the majority within the party and were thus not allowed complete liberation.

Within AMNLAE there was a debate over the structure of the movement. One side argued that the AMNLAE should be directed by women at the base. The second group maintained that it was necessary to keep the organization hierarchical which ultimately allowed the FSLN to make the decisions and maintain power. In September 1988, AMNLAE changed its name to the Movement of Nicaraguan Women (Collinson, 1990). It also planned to become more democratic and summoned an electoral process. However, elections were postponed and this demonstrated yet again the lack of cohesion and efficiency present in this organization. Collinson (1990) and Disney (2008) point out that there were several women who chose to break away from the revolutionary party and went on to form their own NGOs.

\section{Birth of the Women's Movement from the 1979 Revolution}

However, the bulk of the literature I reviewed was first person narratives of the women who fought in the revolution and who were a part of the creation of the women's organizations from the beginning of the revolution (Randall 1992, Randall 1994, De Volo 2001, Mendez 2005). Randall (1992) points out that several organizations, even those not centered on women, began to take the women's movement seriously as women became politically active. She points out that one of the many reasons for this was declining health statistics that demonstrated illegal abortions were the main cause for deaths of women (Randall, 1992). However, Randall (1992) points out that there was disagreement among FSLN members as to how to deal with the need for a feminist agenda. Randall 
(1992) states that a large proportion of women who were involved in the revolutionary struggle moved on to NGOs and various other areas of the feminist struggle.

\section{Shortcomings of Revolution and $A M N L A E$}

Roger Lancaster's (1992) text, Life is Hard: Machismo, Danger, and the Intimacy of Power in Nicaragua, addresses the shortcomings of the Nicaraguan revolution and the disappointment many Nicaraguans felt because of these failings. Lancaster (1992) describes his theories on the "failings" of the revolution by incorporating women's stories and struggles into his text. Lancaster (1992) provides insight into the daily lives of various Nicaraguans, specifically those of Managuan women. He demonstrates how these lives were transformed, both politically and socially, because of the revolution. In addition, Lancaster (1992) describes the role AMNLAE played in the revolution. Lancaster states, “AMNLAE, whose charter was to defend women's rights within the revolution, emphasized defense of the revolution (to some extent at the expense of women's issues)" (1992:293). Lancaster's (1992) text demonstrates the shortcomings of the revolution, the women's revolutionary party, and may provide insight to how and why many women chose to break away from the Association of Nicaraguan Women Luisa Amanda Espinosa.

\section{Impact of Women's Movement on the Status of Women}

Since the 1990s, there have been several works that pertain specifically to the women's rights movement and the impact the movement had on the status of women. For example, Collinson (1990) points out that women's organizations such as Hablemos de 
Nosotras, La Corriente, and Colectivo de Mujeres have been instrumental for the positive upward swing in the status of women. Collinson (1990) cites organizations such as the Federation of Professional Workers (CONAPRO) who lobbied for domestic violence to be treated as a crime. The Federation of Professional Workers aimed to "propagate public disapproval against potential abusers" (Collinson, 1990:17). Organizations such as the Ixchen Women's Centers were extremely involved at the local level as well. They offered free services such as contraceptive treatment and legal and health advice. These organizations campaigned to educate the masses of women on their rights guaranteed to them under the new FSLN Constitution. Collinson (1990) believes that through political participation, women have gained the self-confidence to defend their place in society and have learned how to organize themselves.

\section{Economy and its Impact on Women's Movement}

Some scholars chose to investigate the economic impacts of various policies in Nicaragua that affect women, such as neoliberalism. Babb (2001) explored the ways in which Nicaraguan society has adapted to the stimuli of neoliberalism. She visited urban cooperatives, government offices and research centers to collect data to make sense of the drastic changes taking place in Nicaragua (Babb, 2001). Babb (2001) recognized the revolution as a stimulating factor for the women's movement. She states that women have been the ones most affected by the economic policies in Nicaragua (Babb, 2001). Babb (2001) states that the movement has led to the increased participation of women in various organizations that cover issues such as violence, maternal health, and gay and lesbian rights. Babb (2001) demonstrated that no matter what the economic 
circumstances are, women organizations have been able to organize and participate effectively. Metoyer's (2000) work addresses the connection between the actions of the state and gender relations. Most importantly, Metoyer (2000) assesses the women's movement and its growing political power. Metoyer (2000) was an observer and volunteer in Nicaragua and uses stories and interviews to link the personal struggles of the women who participated in the movement to the movement itself. Metoyer's (2000) text distinguishes itself from the other texts that utilized first-hand accounts. She analyzes gender relations through the lens of neoliberalism. Neoliberal policies impacted the financial flow to NGOs and thus are important to know in order to measure the success of these organizations.

\section{How Gender has developed through Social Movements}

Chant and Craske (2003) examine how gender has developed through social movements, sexuality, health and other social phenomena. Chant and Craske (2003) question whether gender inequality has actually diminished in the twenty-first century and if so, why and how it has changed. Chant and Craske (2003) determine that one of the most important factors for the empowerment of women is the role of nongovernmental organizations. Craske (2003) questions whether women have become more empowered through the work of nongovernmental organizations. She then questions whether indicators such as the United Nation's Development Programme (UNDP) Gender Empowerment Measure (GEM) are effective tools for measuring this

complex question. She speculates that it is difficult for women to move beyond personal empowerment and organize on a mass level to achieve social goals (Craske, 2003). 
Craske concludes that crises have demonstrated their effectiveness in stirring up the need for social movements. She states that these social movements, involving actors such as NGOs, have increased the visibility of women and has made gender and gender relations parts of "public life" (Craske, 2003:69).

\section{Transnational Processes and Impact on NGOs}

Mendez (2005) addresses the transnational, national and local processes and how they interact to shape local movements. Mendez (2005) describes Maria Elena Cuadra (MEC), an autonomous women's organization that addresses the women's role in the workplace and within unions. Mendez's (2005) research was gathered from first-hand narratives of women who began MEC and from her experience as a volunteer with the organizers from the organization. Mendez's (2005) work addresses many other NGOs and raises an important question for her readers: Do NGOs work through a participatory democratic process or do they embody a hierarchical power dynamic? Mendez also points out that feminists have been worried about what is referred to as the "NGO-ization of Latin America" (2005:216) Mendez states, "the feminist movement has become preoccupied with the idea that these organizations are less focused on developing ties to a social base and more on supplying services to women." (2005:216). Mendez points out a crucial issue that is not emphasized in most works focused on NGOs: "MEC has struggled with achieving a balance between grassroots work and also being 'professional enough' to sustain its efforts through continued financial support from NGO donors" (2005:216). Mendez's (2005) text raises a valid question: Do NGOs suffer from a lack of funds because of their lack of professionalism? If there were more funds available to 
NGOs, could they have a more positive impact on the status of women? Mendez (2005) concludes that MEC only maintains its independence from the government because it is financially dependent upon IGOs.

There have been several studies that highlight the progress of NGOs and the transnational partnerships they have formed. Maier and Lebon's (2010) text highlights the ways in which women, including Afro-Latinas, lesbians, and indigenous women incorporate themselves into the call for social action. Lebon (2010) states that there is currently a broader network of organizations and women must learn the process of policy making at the local and international level. She notes that although there have been numerous women's movements worldwide, all women's struggles have become focused on "expand(ing) political, social and economic citizenship" (Lebon, 2005:4) However, Nicaragua's women's movement differs slightly from the others. Nicaraguan feminists have recently pushed for less hierarchical networks. Other women's organizations across the globe have been more receptive to becoming a part of larger, transnational networks, which inherently, are part of rigid hierarchical structures. These fixed structures usually require lengthier decision making processes and are disconnected and misunderstood by the local populations they affect. There appears to be very few texts that address this shift in organizational patterns. It remains to be seen how this will affect Nicaragua's NGO successes.

Yet, as Kampwirth (2010) points out, there are a number of antifeminist groups to take into consideration. Antifeminists groups are equally powerful in the state where many of the antifeminists hold positions as elected officials. The current feminist 
movement faces strong opposition. Daniel Ortega's administration has decreased the amount of space for women to organize effectively. The current government has also decreased accountability to programs specifically for combating domestic violence and providing literacy programs and health facilities.

Naples (2002) brings to attention the various social actions women are taking part in in order to challenge global inequality. She points out that most literature on globalization broadly describes the economic and political changes (Naples, 2002). However, most of this literature frequently fails to mention women and the impact of global change upon them. Naples (2002) highlights the progress taking place as a result of cooperation of local organizing efforts and global organizing efforts. Several authors normally describe that the labor movement is the only movement in which women have contributed to significantly. However, Naples chose to highlight various case studies that demonstrated a move toward, "sustainable transnational feminist movements" that encompass more than just labor organizing (2002:4). One of these case studies by Clare Weber describes one particular organization, the Wisconsin Coordinating Council on Nicaragua (WCCN). Weber states that the WCCN originally began as a movement in the United States to end military intervention in Nicaragua. However, the organization shifted its primary purpose after the revolution to adapt to the political climate. Since the 1990s, the WCCN has worked to, "challenge the gendered and racialized effects of global economic restructuring in Nicaragua" (Naples, 2002:45) According to Naples (2002), the WCCN works with several other organizations both locally in Nicaragua and all over the world, to reform the global theories of First World and Third World feminisms. Naples 
states that the WCCN has been able to handle power differences and hegemonic advances because of its "multicultural and multiracial feminist standpoint" (2002:45).

Disney (2008) gathers stories and personal experiences from Nicaragua and Mozambique to provide vivid case examples of third world feminist movements. Disney states, "I am telling a story of feminist agency: a transformation from mobilization to participation to organization" (2008: Preface,x) Disney (2008) describes the autonomous women's organizing efforts and the organizations that have stemmed from the main women's organizations, i.e. AMNLAE. Disney (2008) states that to work independently from the state maintains a women's "bodily integrity". She points out that it is the NGOs that are addressing women's rights, such as the freedom to have children and to be free from violence (Disney, 2008). Disney (2008) also raises a valid theoretical question in her text: Are the feminist movements occurring in both Nicaragua and Mozambique vastly different than those in the Western hemisphere of the world? Disney's observation questions whether the theoretical foundation of feminism is the same for all women's movements or whether the women's movements in Nicaragua and Mozambique are unique or how can Nicaragua's experience add to the growing understanding of feminism and its theoretical framework. Disney (2008) states that Nicaraguan feminist organizations have each chosen different organizational tactics. Feminists across the globe are challenging the constructions of our current society: "productive vs. reproductive", "economics vs. sexual violence". Disney (2008) focuses primarily on the NGOs within Nicaragua, the difficulties that they face, such as Machismo, and their struggle to achieve consensus on whether or not to employ a vertical hierarchical order 
within their respective organizations. However, this text provides an improved understanding of what is occurring internally in the NGOs in Nicaragua and whether their conditions will improve. Most importantly, however, Disney (2008) states that there have been significant impacts made on Nicaragua society due to the continuous efforts of the NGOs. Disney (2008) is a contemporary author and thankfully addresses some of the more recent issues facing NGOs today. For example, Disney (2008) cites the restrictive abortion law of 2006 as a setback for the work that many of the NGOs accomplished in the past. Disney (2008) perhaps echoes what previous authors stated: the women's movements and the NGOs that comprise them have lost patience with the powers of the state and church.

Similarly, Macdonald (1997) compares two countries: Costa Rica and Nicaragua. She gathered first-hand accounts from Nicaraguans while conducting field research from 1988 to 1989 (Macdonald, 1997). Macdonald suggests that NGOs are credited with engaging and improving civic societies all over the world (1997:6). Macdonald (1997) traces the origins of NGOs and concludes that NGOs are no longer considered peripheral actors. However, Macdonald (1997) warns that the impact of NGOs on civic societies cannot be measured too simplistically. She states, "NGOs are part of a long-term, openended process, constantly reshaped by new trends in the international political economy, as well as by the shifting relationship between state and civic society in both North and South"(1997:5).

Macdonald's (1997) text points out the exact timeline for the emergence of International NGOs and IGOs. According to Macdonald (1997), once Somoza was out of 
power, the formal, two-party system ended. International NGOs were allowed to participate in Nicaraguan politics and to engage in organizing civic societies. She states that Nicaraguan NGOs evolved from the political process taking place in Nicaragua. As she points out, Nicaragua's NGOs did not follow the steady process from "charity and relief" to "development to political involvement." (Macdonald, 1997:99)

Lebon (2010) states that since the 1970s there has been a significant increase in the "rich literature" by feminist scholars. There appears to be a wide selection of texts related to the origination of many NGOs in Nicaragua and the process by which many of the women's organizations became autonomous from the women's revolutionary party. Very few authors have chosen to link the work of NGOs and IGOs. The texts regarding Nicaragua's feminist movement before the revolution in 1979 appear to be lacking as well. The emphasis for most of the literature related to the creation of NGOs has been on the revolution and the impact it had on Nicaraguan society. However, many authors do not include the work of IGOs in their text. Nor do they include the transnational partnerships that IGOs have formed recently. Nevertheless, the literature pertaining to Nicaragua seems to be growing. The literature suggests that interest in Nicaragua, its social movements, and the creation of organizations spawned from the social movements, will continue to grow due to the controversial political party in power.

\section{Theoretical Perspective}

My study will examine the relationship between NGOs and civic society and determine how the political interactions between these entities led to the creation of a women's movement in Nicaragua and whether these organizations continue to make an 
impact on the status of women. Laura Macdonald argues that NGOs have arisen as the chief contenders to promote "just and democratic forms of development." (1997:3) Christina Ewig in her article, “The Strengths and Limits of the NGO Women's Movement Model: Shaping Nicaragua's Democratic Institutions," states, "Analysis of the NGO-based feminist movement in Nicaragua... will yield insight into the ability of NGO-based women's movement to influence state policy and into the strengths and weaknesses of using NGOs as an institutional base on which to build a social movement in civic society." (1999:77)

Helen Collinson (1990) argues that the Sandinista Front for National Liberation (FSLN), which took over power in Nicaragua following the revolution, was committed to the women's movement and the creation of NGOs that served the women's movement ( $p$. 1). Macdonald (1997) argues that the NGOs created under the FSLN were allowed to become more influential because they did not demand autonomy from the FSLN (p. 97). However, women's interests were secondary to the interests of the FSLN (Metoyer, 2000: 4). Metoyer argues that women used "individual and collective negotiation" to gain a larger social and political space (2000:10). Collinson (1990) argues that the growth of NGOs led to the creation of a civic society that now supports Nicaragua's peoples and facilitates Nicaraguan governmental policies. According to the United Nations Human Development Index, the HDI has increased in Nicaragua since 1980. Florence Babb attributes this rise in HDI to the creation of a civic society which is composed of a shrinking state and a significant social movement (2001:205). 


\section{Chapter Summary}

This chapter demonstrates how the literature fits this study. Several authors garner first-person narratives for their work and some rely on statistical analysis taken by NGOs based in the United States. Topics in this section range from the birth of the revolution, to the Catholic Church's role in the Women's Movement, to the transnational processes that have impacted the Women's Movement and the creation of NGOs. This chapter also provides the theoretical framework for this study. We observe whether civic society building does impact the status of women in Nicaragua specifically, and to what extent.

In the next section, we explore the methodology that was utilized to test this theory. This study utilizes a triangularization approach and collects data from archival research, interviews, and surveys. The next chapter will also provide the hypotheses for this study as well as an explanation on how these hypotheses will be tested. 


\section{CHAPTER III: METHODS}

\section{Introduction}

For this study, I utilized a triangularization approach for analyzing the influence of women's organizations in fostering women-friendly state policies. First, I gathered archival data from the Florida International University library and from the internet. I gathered data from books, journals and newspaper articles. I also collected the United Nations Development Programme's data from its Human Development Reports. From these reports, I garnered quantitative information on Nicaragua's historical ratings on the Human Development Index.

Second, I interviewed representatives from several well-respected nongovernmental organizations, which I will refer to as "elite interviews." I interviewed a representative from Working Capital for Community Needs (WCCN), a United Statesbased NGO. In addition, I interviewed representatives from seven local nongovernmental organizations in Managua, Nicaragua. The organizations I interviewed were Centro de Mujeres (Women's Center), Colectivo de Mujeres 8 de Marzo (March $18^{\text {th }}$ Women's Collective), Movimiento Autonomos de Mujeres (Autonomous Women's Movement), Centro de Prevención de la Violencia (Center for Prevention Against Violence), Red de Mujeres Contra la Violencia (Network of Women Against Violence), Centro de Información y Servicios de Asesoría en Salud (the Center for Information and Health Services), and Puntos de Encuentro (Point of Contact). I also interviewed a representative of the United States Embassy from the Political Affairs Office in Managua. Each interview lasted approximately one hour. I chose Managua because it is 
the capitol and the variables for this study are more visible in Managua than any other city in Nicaragua. Managuan NGOs have the biggest impact on policy because of the resources and proximity to policy makers that their location in the capitol affords.

Lastly, I distributed surveys to employees of the aforementioned organizations. These employees were chosen by the representative I interviewed of each organization and in no way were selected by myself, the researcher. The constituents of the sample chosen by each of the representatives were members who were familiar with the services offered by the nongovernmental organizations. A majority of the members selected to participate in the survey worked for the NGO at the time of questioning. The survey required a half hour to complete.

\section{Part I: United Nation's Development Programme: HDI}

\section{Human Development Index}

The ultimate goal of this thesis is to determine how the women's movement and NGOs influenced state policies to benefit the welfare and well-being of citizens. The HDI is perhaps the best known composite index of social and economic well-being. The HDI is widely recognized as an important policy tool useful for monitoring and evaluating human welfare and measuring human development (Jahan 2002). The HDI is a composite index used to measure human development. The HDI ranges from a low of 0 , indicating low human development, to 100 designating high human development. According to the United Nations Development Programme (UNDP): 
The Human Development Index (HDI) is a summary measure of human development. It measures the average achievements in a country in three basic dimensions of human development: a long and healthy life (health), access to knowledge (education) and a decent standard of living (income). Data availability determines HDI country coverage. To enable cross-country comparisons, the HDI is, to the extent possible, calculated based on data from leading international data agencies and other credible data sources available at the time of writing (UNDP Online).

The data are gathered and calculated by various United Nations' agencies. The United Nations Department of Economic and Social Affairs (UNESCO) measures life expectancy at birth. Barro and Lee gather and calculate the means years of schooling while the UNESCO Institute for Statistics measures the expected years of schooling. The World Bank (WB) and the International Monetary Fund (IMF) provide the statistics on GNI per capita. ${ }^{1}$ The HDI measures life expectancy at a minimum value of 20 years and a maximum value of 83.4 years. Access to knowledge is measured by the average years of adult education by people age 25 and older as well as the expected years of schooling for school-entrance age children. ${ }^{2}$ The HDI uses the Gross National Income per capita to measure the standard of living. The HDI reports are available from 1980-2011.

The HDI is instrumental to this study because it provides a metric to measure progress. HDI will demonstrate the increase and decrease in value of life expectancy,

\footnotetext{
${ }^{1}$ According to the UNDP, "Many data gaps still exist in even some very basic areas of human development indicators. While actively advocating for the improvement of human development data, as a principle and for practical reasons, the Human Development Report Office does not collect data directly from countries." http://hdr.undp.org/en/statistics/hdi/

${ }^{2}$ Ibid, Changes to the HDI, Indicators, http://hdr.undp.org/en/statistics/hdi/
} 
access to knowledge, and the standard of living. The HDI is especially important when determining the value of progress for women. Women's organizations have structured their organizations to offer services and implement policies that cater to the values the HDI measures. The HDI is a tool in which we can observe whether these organizations' efforts have assisted women in obtaining a higher quality of life.

\section{Part II: Interview Process}

I relied on the strategies of Craig Leonard Brians et al., the authors of Empirical $\underline{\text { Political Analysis, }}$ while planning my interviews. According to Brians, the interviewer must use a conversational style when performing the interview and be familiar with his or her questions in order to reduce error during the interview process (2011:168). In addition, the interviewer must not alter the wording of his or her question depending on the respondent. Furthermore, an interviewer must always be equipped to answer questions regarding the purpose and scope of his or her study. Brians states that a researcher must "protect their respondents from harm and ensure that all survey findings are reported accurately" (2011:176). Brians suggests observing the following ethical considerations: 1. Respondents right to know, 2. Respondents' right to protection, 3. Respondents' right to privacy, 4. Respondents' right to confidentiality and anonymity and lastly, 5. Accurate reporting of results (2011: 176). I utilized Brians' method of conducting interviews. First, I memorized all of my questions and became familiar with how I was going to ask them during the interview. Second, I explained to each interviewee the purpose of the study and who they could contact if they needed more information. Next, I provided each respondent with a consent form in their native 
language, Spanish, approved by the Institutional Review Board through Florida

International University's Office of Research Integrity. Then, I recorded all interviews and made sure to record whether the respondent preferred the conversation to remain confidential or anonymous. Lastly, upon return to the United States, I safely secured all documentation under lock and key.

\section{Preparing for the Interview}

In order to prepare for the interview process, I took the appropriate measures as determined by the Institutional Review Board and completed the Social and Behavioral Responsible Conduct of Research course as well as the Human Subject Responsible Research course through the Collaborative Institutional Training Initiative. All of the questions for the elite interviews, email scripts, and consent forms, including translated documents from English to Spanish gathered during this process, were approved by the Institutional Board Review through the Office of Research Integrity at Florida International University. See attached Appendix 1.

\section{Interview Collection}

I traveled to Managua, Nicaragua from November 12, 2011 until November 22, 2011, funded by a Tinker Field Research Grant administered by the Latin American and Caribbean Studies Center at Florida International University. The questions asked during the elite interviews were: 
1. What do you believe are the benefits that this organization provides to the community?

2. Have you benefited directly from this organization? Are you aware of any other organizations that provide these services?

3. What do you think are the issues most affecting women in your community? Do you believe this organization has addressed these issues?

4. What would you like to see more or less from this organization?

5. What policies do you think the government ought to enact to ensure equality of women in Nicaragua?

6. How were NGOs an integral part in the evolution of the women's rights movement?

7. How did NGOs contribute to the women's rights movement?

8. How did your specific organization help push forward the goals and ideals of the women's movement in Nicaragua?

9. What, if any, are the connections/links between your NGO and other NGOs? What could your specific organization do better?

10. What could other NGOs do better?

11. What is the greatest obstacle to achieving women's equality in Nicaragua? (lack of police attention, lack of legislation, lack of political will, lack of financial support, etc).

12. How is your organization overcoming these obstacles?

13. How has the government helped/hindered your work? 
14. How much influence do you believe your organization has on local and national politics/government?

Out of the eight NGO representatives that I interviewed, seven were women from Managua, Nicaragua. For the purposes of this study, each interviewee agreed to let me use their names and information they provided during the interview. Fátima Millón was Director of Development for the Centro de Mujeres. Ms. Millón explained to me that the Center is a part of a larger network of women's organizations and had been open for 21 years. The Centro de Mujerees (the Women's Center) specializes in working on eradicating violence against women. It also provides medical services to women, specifically gynecological and psychological services. They advocate for reproductive rights, attacks on which she stated were another obstacle that the women's movement is currently facing.

Maria Virginia Meneses Mendoza was Director of Legal Counsel for the Colectivo de Mujeres 8 de Marzo. I was supposed to meet with Luz Marina Torres, the Director of the organization, but unfortunately she was not available for an interview. Ms. Torres was a founding member of AMNLAE and then was instrumental in the separation from the organization in 1980. Ms. Mendoza informed me that Ms. Torres felt as though AMNLAE did not respond to women's needs. Currently, the Collective works alongside other women's organizations such as Red Contra la Violencia, Maria Elena Cuadra, and Xochtil.

Juanita Jimenez was Director of the Movimiento Autonomos de Mujeres. Ms. Jimenez pointed out that this organization has been active for over 30 years and has been 
a constant figure in the women's movement. She stated that her organization works to advance democracy through activism. Her organization works with the Redes as well and points out that all the women's organizations are intent on equality for women. Ms. Jimenez argues that the women's movement is not only about advancing the rights of women, but advancing the rights of men as well.

Mónica Zalaquett was Director of the Centro de Prevención de la Violencia. The center has worked for 15 years on the prevention of violence. The center works primarily in districts four, five, six and seven, the districts that Ms. Zalaquett stated are the most plagued with violence. The Center for Prevention's purpose is slightly different than most of the organizations I interviewed. The center works to change the authoritarian system that is prevalent in Nicaraguan schools and homes. It is the only organization with the specific focus to change each Nicaraguan machista man. Ms. Zalaquett stated that if the machista mentality is not changed in school, starting with boys and girls from a young age, Nicaraguan society will never change.

Marie Elena Dominguez was the Relations Coordinator for the Red. Ms. Dominguez stated that this organization was created 20 years go and, since its inception, has worked with various collectives. In addition, they work with various groups and foundations from Nicaragua and all over the world. The organization also provides services to casa de mujeres, centers that were created specifically to meet the needs of women. They offer medical services including gynecological and psychological services. Their mission is to transform the relationships that patriarchal society reinforces because it is these relationships that are the cause for violence against women (Vázquez 2010:12). 
They work with women and for women specifically in the terms of their health, economy, education, communication, and sexuality. They also work on the prevention of violence against women.

Ana Quiros Viquez was the Co-Director for the Center for Information and Health Services. The center began in 1983 and has been working as a part of the feminist movement to bring political justice to Nicaraguans. Ms. Viquez believes that violence is the biggest problem Nicaraguan women face. She clarified that this can be institutional violence as well as private violence. The center focuses on educating women that violence is not natural and how not to be a victim of violence. They work with schools and men to change the apoya, or effectiveness, of violence.

Hazel Jirón was the Representative Manager for Institutional Projects for Puntos de Encuentro. Point of Contact has been working for 20 years in the feminist movement. They are dedicated to constructing human rights focused on diversity within the feminist movement. They educate women about their human rights, reproductive rights, economic rights, and violence. They work with 240 other organizations in Nicaragua, El Salvador, Guatemala, and Honduras to exchange information and to fortify their capacity. They also produce a magazine called La Boletina, of which 26 million are distributed to the aforementioned organizations and the general Nicaraguan populace. In addition, the organization also broadcasts a national radio program where topics range from the urban youth, sexual abuse and various topics within the feminist movement.

The representative from the United States Embassy in Managua was a man named Daniel Carroll from the United States. Mr. Carroll works primarily with NGO 
representatives on the Atlantic Coast of Nicaragua, but he has worked and continues to work all over Nicaragua. He works with numerous women's organizations all over Nicaragua and was well versed in issues affecting the women in this country. Mr. Carroll informed me that the women's organizations and several other NGOs and IGOs receive funding from the United States Agency for International Development (USAID). His primary responsibility is to highlight the issues affecting women and determine whether their human rights are being violated. He has written several reports to share with the State Department and with other NGOs and IGOs.

The first interview was conducted in Miami, FL via Skype with Luis Carlos Arenas, Executive Director of WCCN on November 1, 2011. Mr. Arenas was the only man that was interviewed from the NGOs and he is from Colombia. The organization has been working since 1984 to advance economic and social conditions in Nicaragua. Originally the organization had two purposes. The first was to establish a relationship between feminists in the United States and feminists in Nicaragua. The second purpose was to establish an economic fund and provide loans to Nicaraguans. However, the organization's purpose has since changed. According to Mr. Arenas, his organization has been more successful in finding funding for private loans and has shifted their focus more on micro financing. WCCN has 1500 or so supporters and $\$ 60$ million dollars has gone to providing finance loans to Nicaraguans and funding programs in Nicaragua. He pointed out that it was much more difficult to gain support for the women's initiative because it was harder to measure the success of that program and to gain monetary support. Mr. Arenas works informed me that the women's initiative began with three organizations in 
Managua, but now his organization works all over Nicaragua distributing micro finance loans. He is familiar with women's NGOs in Nicaragua from his previous experience.

The respondents were entirely self-selected, although I was assisted in obtaining NGO contact information by Luis Carlos Arenas of WCCN. Mr. Arenas' NGO has two offices, one in Madison, Wisconsin in the United States and one in Managua. Mr. Arenas provided me with the names and positions of representatives of the organizations that would be helpful to this study. I performed an online search of the NGOs to verify that the listed individuals were legitimate representatives and concluded that the information Mr. Arenas provided me was true and accurate. These representatives were chosen because of their position and experience in their respective organizations.

\section{Sample Size}

The size of my sample was nine representatives for elite interviews. I recognize that this is a relatively small sample but I chose these organizations for their established expertise in their respective fields. The majority of the representatives of these organizations was college educated and middle class and worked with the population in Managua. However, upon further investigation, I learned that these representatives worked within the seven districts in Managua and represented an extremely diverse population of Nicaraguans, not just Managuans. Estimates show that there are roughly 934,000 people living in Managua compared to 5,666,301 people living in Nicaragua as a whole (CIA World Factbook Online). A large proportion of Nicaraguans either move to Managua to find work or commute to Managua to work. I gathered this information from the interviews as well as speaking with people on a daily basis. Thus, I was able to glean 
information representative of the whole population of Nicaragua because of the respondents' relationship with the Managuan population. Furthermore, some of these representatives worked with populations outside of Managua, such as Mr. Carroll, who worked primarily with Nicaraguans on the Atlantic coast. These trained representatives interacted with the local population on a daily basis and were able to speak on behalf of the populace.

Face-to-face interviews were employed for the interview process. Before departing for Managua, I conducted an interview via Skype with Luis Carlos Arenas of WCCN on November 1, 2011. I arrived to Managua on November 12, 2011. On Monday November 14, 2011, I met with Fátima Millón, Director of Development of the Women's Center, and interviewed her for approximately one hour. I met with Maria Virginia Meneses Mendoza, Director of Legal Counsel for the March $18^{\text {th }}$ Women's Collective, on November 15, 2011, and interviewed her for one hour. On November 16, 2011, I met with Daniel Carroll of the United States Embassy in Nicaragua and interviewed him for one hour. I met with Juanita Jimenez, Director of the Autonomous Women's Movement, on November 17, 2011 and interviewed her for one hour. On November 18, 2011, I met with Mónica Zalaquett, Director of the Center for Prevention, and conducted an in person interview for one hour. I met with Marie Elena Dominguez, the Relations Coordinator for the Network of Women Against Violence, and Ana Quiros Viquez, Co-Director for the Center for Information and Health Services, on November 21, 2011 and interviewed them each separately for one hour. On November 22, 2011, I interviewed Hazel Jirón, Representative Manager for Institutional Projects from Point of Contact, for one hour. 


\section{Part III: Survey Collection}

In order to prepare for the survey collection, I took the appropriate measures as determined by the Institutional Review Board and completed the Social and Behavioral Responsible Conduct of Research course and the Human Subject Responsible Research course through the Collaborative Institutional Training Initiative. All of the questions for the surveys, as well as the consent forms gathered during this process, were approved by the Institutional Board Review through the Office of Research Integrity at Florida International University. See attached Appendix 2.

Members of each organization were asked to fill out a survey pertaining to this study. The members were asked:

1. What is your affiliation with this organization?

2. What are the services that this organization provides to the community?

3. Have you benefited directly from this organization?

4. Are you aware of any other organizations that provide these services?

5. Do you believe that this NGO benefits your community?

6. What do you think are the issues most affecting women in your community?

7. Do you believe this organization has addressed these issues?

8. What would you like to see more or less from this organization?

9. What is your greatest need as a women and citizen of Nicaragua?

10. What policies do you think the government ought to enact to ensure equality of women in Nicaragua? 
Out of the eight NGOs that I surveyed, I was able to gather three additional surveys from individual members of two of the aforementioned organizations to better understand the workings of the NGOs. All three members are women. All surveys were conducted in the offices of the respective organizations. For the purposes of this study, the interviewees agreed to let me use their names and personal information collected from the interview. The first survey was collected on November 15, 2011 and was completed by Marta Araez Rosales. Ms. Rosales was a doctor for the Colectivo de Mujeres 8 de Marzo and was 50 years old. When asked what her affiliation to this organization was, she stated that she is a feminist who believes in women's rights. Ms. Rosales stated that the community in District 6 depends on the services offered by this organization.

The second survey was collected on November 18, 2011 and was completed by Juana Antonia Vanegas. Ms. Vanegas was the Methodology Unit Manager for the Centro de Prevención de la Violencia and was 29 years old. Ms. Vanegas is responsible for gathering data about members from conferences and annual projects and evaluating the data for the organization. She stated that she feels that this organization is unique because it provides services targeted to children in order to change society's mentality starting from a young age. She believes the greatest obstacles women face are interfamily violence, unemployment, and sexual and psychological abuse.

The final survey was collected on November 18, 2011 and was completed by Ivette Espino. Ms. Espino was a Psychologist for the Centro de Prevención de la Violencia and was 32 years old. Ms. Espino has worked for the center for nine years. She 
offers psychological services to families, schools, and the community. She also assists in organizing conferences focused on psychological services where she gives talks on selfesteem and personal growth. She believes the center provides her with as many services as she provides her clients. "It (the center) has allowed me to enrich my knowledge and has allowed me to grow personally and support the people they serve" (Author's interview, November 18, 2011).

\section{Hypotheses}

There are four hypotheses that will be examined in this paper:

Hypothesis 1: The women's movement provided the necessary tools for women to form their own NGOs.

I posit that the women's movement, which stemmed from the 1979 revolution, created women's NGOs. How NGOs were created is demonstrated through evidence gathered from archival research and interviews. The women's movement, which spawned from the separation from the revolutionary party the FSLN, led to the creation of NGOs. For example, the women's movement increased awareness for women's issues providing motivation for women to form NGOs.

Hypothesis 2: The existence of the women's movement pressured the state to implement policies specifically for the benefit of women.

I postulate that the women's movement influenced and initiated policies to be implemented by the government. I rely on archival documents including the Nicaraguan 
constitution, elite interviews, and surveys, to demonstrate that policies were implemented by women's NGOs.

Hypothesis 3: Traditional elements of society have extorted pressure on the state to maintain traditional gender roles

I theorize that patriarchal institutions, such as the Catholic Church, along with deep seated social factors such as machismo, have pressured the state to maintain traditional gender roles. I rely on archival documents, elite interviews, and surveys, to demonstrate the impact these traditional elements have had on Nicaraguan society.

Hypothesis 4: The women's movement through the creation of NGOs and the transformation of state polices benefited the status of women.

Lastly, I compare contemporary values of HDI to measurements taken in the past to evaluate changes in the status of women. I also compare the responses from the elite interviews and the surveys with the members of the organization. In sum, this study is determined to answer whether the women's movement, which implemented state policies and led to the creation of NGOs, has had a significant impact on the status of women.

\section{Chapter Summary}

This chapter defines the UNDP's HDI. In addition, it demonstrates how to conduct interviews and how I chose to conduct interviews for this study. It also provides the necessary information on the representatives I interviewed as well as the members who completed the survey. I also outline the four hypotheses of this study. 
This chapter also provides the framework for which the next chapter will demonstrate the findings. We observe the results of the interviews, surveys and the archival research. The next chapter weaves together the many theories and hypotheses that have been woven thus far. 


\section{CHAPTER IV: FINDINGS}

\section{Introduction}

The findings of this paper are based on a broad spectrum of evidence drawn from many sources. The archival information was gathered from various sources, including books, journals, magazine articles, and newspapers. Most of the material was found online or in the Florida International University Green Library. Most of the interviews discussed in this chapter were collected in Managua, Nicaragua. One of the interviews was conducted online via Skype between Miami, FL and Madison, WI. The surveys collected for this study were, like the majority of interviews, gathered in Managua. The statistical information was sourced from the United Nations Development Programme's Human Development Report. The chapter concludes by bringing together the hypotheses, theoretical framework, and statistical information to evaluate whether the status of women has been affected by NGOs.

Perhaps the most eye opening portion of this study comes from the women who are directly involved in this movement. Before I had the privilege of traveling to Nicaragua to learn about the women's movement, I had only read about the strife women face on a daily basis. The present study opened my eyes to the most devastating issues affecting Nicaraguan women. In addition, I was able to gather first-hand accounts of how these organizations operate collectively. Furthermore, I gained information on how they interact with their local and national government. It was a truly wonderful experience and I am grateful that I was able to observe the work that these organizations are doing. 


\section{From Women's Movement to Women's Organizations}

As mentioned in Chapter I, women began to break away from AMNLAE. Although in 1987 the FSLN proclaimed to make women a priority, AMNLAE and the interests of women began to take a backseat to the FSLN's priorities. However, in order to demonstrate state support for women's rights, the Sandinista government funded research projects and called for action through the creation of the Instituto Nicaraguense de la Mujer (INIM) (Nicaraguan Institute for Women). In addition, organizations such as the Asociación de Trabajadores del Campo (ATC), (Farm Workers Association) and the Unión Nacional de Agricultores y Ganadores (UNAG) (National Union of Farmers and Ranchers of Nicaragua), were created, "to build a broad mass movement to promote women's interests and leadership in all political institutions and organizations" (Metoyer, 2000:29). These organizations were created in 1989 after the FSLN saw the difficulties women were facing in the work sector. Metoyer argues that the Sandinista government was concerned about economic changes and not political changes. Thus, it would make sense for the Sandinista government to advocate for women to join the work force.

These organizations, and the work they provided women, allowed women to become more politically conscious but still did not address issues at home. Women were still largely responsible for domestic responsibilities. Women's burdens had been tripled: they had to join the labor force, maintain their political activism, and care for their families. Furthermore, women were still unequal to men because of their responsibilities to their families and home, which were seen as a women's burden. In 1987, a TV program for families called "Sexo y Juventud" demonstrated the husband washing 
clothes. The program for some was seen as outrageous, as washing clothes was essentially a woman's task. After the Proclama established, "an effective solidarity within the couple with respect to domestic chores and family responsibilities," the government began to broadcast commercials that showed little boys cleaning their bedrooms (Collinson, 1990:32). Women continued to face inequalities in both home and work, but they were not the only ones aware of the extra burdens at home as men became more conscious of women's extra burdens.

Although these organizations made significant strides for women, it was not enough for the women's movement and its leaders. Women began, through various outlets, such as joining CEBs and the labor force, to become politically conscious of their condition. The Sandinista government, after losing to Violeta Chamorro in 1990, proceeded to reevaluate their Sandinista-affiliated organizations and various autonomous organizations through a series of workshops. It was proposed that the women's movement would become an autonomous movement which would be publicly recognized at the National Women's Meeting. AMNLAE rejected the proposal and many women's organizations began to part from AMNLAE in the early 1990s to, "embrace a broader and more radical political program for women-one they themselves would define" (Babb, 2001:206).

Autonomy for the Women's Movement after AMNLAE

The Comité Nacional Feminista (CNF), or National Feminist Committee, was formed in January 1992 as a response from feminists who felt that AMNLAE did not serve the purposes of women (Stephen 1997:61). The Comité Nacional Feminista was 
comprised of several networks of women's organizations. These networks of women's organizations were committed to "participatory democracy and consensus decisionmaking, and they endorsed the following agenda: fighting violence against women, insisting on respect for different sexual preferences, defending voluntary motherhood, and fighting all forms of oppression, including those based on race, sex, ethnicity and age" (Stephen, 1997:61).

However, after several attempts of trying to find a cohesive message and action plan, the CNF disbanded one year after its formation (Stephen, 1997:61). Although the feminist movement had suffered from a standstill in pushing forward an agreed upon agenda and purpose, the feminist and women's organizations continued to work together. The CNF was able to network a national and Central American regional group of feminist and women's organizations in its short life span. Feminist organizations and women's organizations from all over Central America attended the first Central American Feminist Encuentro in 1993. This First Encuentro allowed women from these various countries to network and garner ideas and inspiration from each other. However, the CNF was established once again two years later by some of the former groups (Babb, 2001:207). The feminist and women's organizations continuously hold meetings and workshops to learn and grow from each other to this day.

Thus, as the abundance of literature and the interviews reveal, Hypothesis 1 has found support. The women's movement was vitally important for the creation of women's NGOs. 
Impact of AMNLAE and NGOs on Governmental policy-making in 1980s

All of the following information for the influence of NGOs in the 1980s was gathered from archival research since the majority of interviewees did not work for these NGOs until later years. I collected these data from various books, journals, magazine articles, newspaper articles and online resources. The following data demonstrate how NGOs effectively introduced, wrote, and changed governmental policies from the onset of the revolution to the present. Women's NGOs were largely responsible for policies developed specifically for women and children. In addition, they lobbied for policies affecting their families, health, and education. Before the Sandinistas, women, the elderly and the disabled were often left out of policy making. After diligent lobbying by AMNLAE, state pensions were made available for the elderly, disabled and widows of war. AMNLAE successfully fought for government funding for and expansion of child care centers and local nurseries.

Several policies were successfully lobbied for by AMNLAE in regards to equal pay in the work place, family life, and political rights. One of these policies, implemented in 1981, called the Law Regulating Relations Between Mothers, Fathers, and Children, created equal rights over children for both parents (Collinson, 1990:14). The Constitution declares in Title 4, Chapter IV, Article 72, and is reinforced by the law in 1988 that, "enabled marriage to be dissolved by mutual consent or by the will of either party" (Collinson, 1990:14). In addition, AMNLAE was able to pass a statute stating that women were to be guaranteed equal rights in the workplace. The Luisa Amanda Espinosa Association of Nicaragua Women assisted in ratifying the Constitution in 1986 which, 
“established an eight-hour working day and paid maternity leave" (Collinson, 1990:29).

However, this has not sufficiently improved prospects for women's employment.

According to employers, the government does not provide them the resources to

implement these laws. For example, the law requires that the employer provide a space

for women to feed their children if there are more than 30 women workers (Collinson,

1990:29). In some areas, unions are weak and women must individually negotiate the

terms of their employment. The government lacks personnel and the infrastructure is not

present to enforce the laws (Collinson, 1990:30). Working has allowed some women the

economic freedom to make their own decisions and to step outside of domestic isolation.

However, work has also proved difficult for some depending on the type of work

available or if they have large families. In addition to working, women can spend

anywhere from 9-12 hours a day doing household chores, which includes making food, washing, and hauling water, for their families (Collinson, 1990:31). Nevertheless, the new work legislation has allowed women the choice to work. Other policies, such as the construction of nurseries and child care centers, have allowed women the flexibility to be mothers as well as contributing members of the work force. Ms. Rosales believes that many women are not able to find jobs and are not informed on their rights. In the survey, she stated that the Colectivo de Mujeres 8 de Marzo organization addresses all of those issues. Ms. Rosales believes that in order for the organization to improve, they need more time to educate women in "informal" subjects. Furthermore, she believes that more women need to join the women's movement to defend women's rights. Ms. Rosales stated that there are policies that the government should promote to guarantee equality for women. First, she stated that policies need to effectively allow women the opportunity to 
work. Second, women need more formal education. Children need to be provided schooling, as well, and need formal education on sex and sexual abuse. She also stated that the government needs to ensure that there are no discriminatory policies against lesbians, homosexuals, transgendered, and transvestites. Lastly, strict policies need to control sexual abuse and the government should ensure that those policies are enforced.

The Luisa Amanda Espinosa Association of Nicaragua Women and FSLN proposed the Agrarian Reform and Co-operative laws instituted in 1981. These were the first laws to, “recognize women's equal rights with men in relation to wages, access to land, and cooperative organization" (Collinson, 1990:41). These laws also defined women as, "co-operative members and landowners in their own right, regardless of whether or not they were heads of households or had adult male children to reap the benefits of agrarian reform" (Collinson, 1990:41). These laws were especially helpful to women in rural areas whose problems were often ignored in favor of those of bourgeoisie or middle class women.

With the assistance of the FSLN, AMNLAE, as mentioned before, was able to write the Proclama that truly made significant strides for women in Nicaraguan society. For example, the Proclama states its opposition to, "the physical and moral abuse of women and children, by promoting, on a social and institutional level, ever stronger responses against those guilty of such conduct" (1990:17). The 1987 Constitution laid the legal foundation for preventing violence against women. Article 36 condemns violence against women, and, "guarantees every citizen the right to physical, psychological, and 
moral integrity; it states that cruel, inhuman or degrading behavior is a crime punishable by law" (Collinson, 1990:17).

The Federation of Professional Workers (CONAPRO) made a significant impact on domestic violence against women, as well. At the Women and Law Conference in 1988, they, "recommended that domestic violence be treated as a crime with punishment equal to that administered for any act of violence committed outside the family" (Collinson, 1990:17). They also suggested that a man should be excluded from any political projects if he is found guilty of battering a woman. CONAPRO was extremely vocal about domestic violence and led numerous campaigns to educate the masses. In doing so, they effectively influenced policies through the support that they were able to garner. CONAPRO, along with AMNLAE, also made sexual abuse a priority. They were able to implement longer sentences, up to 30 years, for those convicted of rape or child abuse. The number of years varied according to the age of the child and the exact offense. Mr. Carroll, from the United States Embassy, stated that the issue most affecting women is violence. He explained that violence includes murder, rape, and sexual abuse. The embassy in 2011 witnessed an 86\% increase in cases of violence against women. However, Mr. Carroll pointed out that he believes this increase is due to increased reporting. The embassy adopted a social media platform to promote anti-violence campaigns. Most importantly, women's organizations have increased their public awareness campaigns and have held more demonstrations which have influenced women's political consciousness and governmental policies. He stated that they utilize radio, which is the primary news source for Nicaraguans. He feels that the women's 
organizations need to be strengthened. Legal protections exist, but accountability needs to be demanded of the government by the organizations. When asked what the biggest problem women face in Nicaragua was, Ms. Millon, from Centro de Mujeres, responded promptly that the biggest problem is violence. She clarified that violence includes not just physical abuse, but sexual and economic abuse as well. There have been several cases of men withholding finances from their respective partner in order to establish dominance in the relationship. The Centro de Mujeres (the Women's Center) specializes in working on eradicating violence against women.

Furthermore, women's organizations and unions have also been instrumental in health campaigns. Once in control of the state, the Sandinistas established universal and free healthcare. Women comprised $75 \%$ of the campaign workers who administered vaccines, educated the public on health care, and were trained in the prevention and treatment of disease (Collinson, 1990:97). Women gained experience and training in a field in which they could flourish and allowed them to bring healthcare knowledge back to their own communities. The Sandinista health union, FETSALUD, is a union extremely vocal in support of women's rights in the health sector. They have also criticized the government health cuts and have prevented corruption of administrators (Collinson, 1990:98). Christian Based Communities and AMNLAE were instrumental in the early stages of the Revolution for training health personnel and recruiting midwives (Collinson, 1990:100). The Luisa Amanda Espinosa Association of Nicaragua Women was also responsible for setting up centers in rural areas for pregnant women who were at a high risk. 


\section{Impact of NGOs from 1990s to Present}

The women's movement has faced several organizational and structural issues. However, the feminist and women's organizations have continuously worked together to advance the status of women. The women's movement successfully began several more diverse organizations in the 1990s including groups such as the Asociación de Mujeres Indigenas de la Costa Atlántica (AMICA) (the Altantic Coast Indigenous Women's Association), Red de Mujeres de Matagalpa (Network of Matagalpan Women), Red de Mujeres contra la Violencia (Network of Women against Violence), and the Red de Mujeres por los Derechos Sexuales y Reproductivos (Network of Women for Sexual and Reproductive Rights). The women's movement fought for the approval of the Law 150 in 1992 which criminalizes sex crimes, corruption, prostitution, sex trafficking, and other crimes of this nature (Cuadra, 2010:15). The Nicaraguan government created the Commissary for Women and Children in 1995. This government branch was created due to Law 228, a product of diligent lobbying on the part of the women's movement. The women's movement also led the fight in 1996 to pass Law 230 which mandates the government to prevent domestic violence by providing resources to Nicaraguan citizens (Cuadra, 2010:15).

In addition, women's organizations have made it their goal to inform Nicaraguans on gender issues by establishing women's health and legal clinics (Babb, 2001:207). Organizations such as Puntos de Encuentro (Point of Contact) offer courses on gender and economic development. Central American University (UCA) led the way by offering a gender studies program, one of the first in the region (Babb, 2001:207). The women's 
movement has also rallied around several cases that have become notorious throughout Nicaragua. One example, found in 2003 , is a case that was referred to as "Rosita". Rosita was a nine year old girl who had been raped and impregnated. The feminist and women's organizations demanded that Rosita be allowed a necessary abortion to save her life. The government capitulated and went as far to initiate a sex education campaign for adolescents implemented by the Ministry of Education (Cuadra, 2010:23). In addition, this case demonstrated the need to approve of the Law of Equality and Opportunity, which was passed in the same year. Fairly recent organizations that began in 1999-2005, such as the Movimiento Feminista (Feminist Movement) and the Movimiento Autónomo de Mujeres (MAM) (Autonomous Women's Movement), have also fought heavily for women's rights. Both organizations have assisted in the electoral process and have brought attention to corruption and demanded that the government remain transparent (Cuadra, 2010:24).

The Women's Center advocates for reproductive rights, attacks on which, Ms. Millón stated, were another obstacle that the women's movement is currently facing. Millón stated that in 2006, President Daniel Ortega's administration changed the law to penalize abortion. She feels that although the relationship between women's organizations and the government has historically not been perfect, it has been exacerbated with the passing of this law. However, she feels as though the government and the women's movement are building their relationship once again. Ms. Millón stated that the women's movement does have quite a bit of influence in national politics. The women's movement has influenced public opinion, and as they continue to work with 
IGOs and several other international NGOs, the movement gains traction and notoriety. Ms. Millón pointed out that the movement is autonomous and is responsible for finding their own resources. She stated that although the women's movement may appear to have divisions, it is extremely important to keep in mind that the women's organizations that the movement is comprised of share the same principles.

Again, as the other NGO directors have pointed out, Ms. Jimenez stated that the biggest problem affecting Nicaraguan women is violence. Ms. Jimenez attributes this to machismo and even suggests that it is "impregnated" in Nicaraguan society. She explained that there are resources from the government to treat violence against women, but not to prevent violence against women. Ms. Jimenez stated that the government simply points out what they want to change in the discourse on women, but that what women really need is a political change. Ms. Jimenez stated that the government suffers from a lack of democratic institutions. There may be resources available to women, but the question is not whether they are available. The question is whether the resources available to women are working, and preventing more harm from being done. In addition, Ms. Jimenez pointed out that Nicaraguans believe, "We can't influence the government because they don't listen" (Author's interview, November 17, 2011). She believes there is a divide between the government and the women's movement. However, she believes it should not matter what the movement's relationship with the government is- all that matters is the advancement of women. Ms. Zalaquett theorized that Nicaraguans have become indifferent to crime because they have become desensitized. She stated that the ministries do not have the capacity to do their work; rather, it is the women's 
organizations, such as the center, that perform the duties of these ministries. She specified, "We help the state, the state doesn't help us" (Author's interview, November $18,2011)$. Although there appears to be a lack of cooperation between the state and the Centro de Prevención, the center has no problem working with other Central American countries to build partnerships transnationally. They work specifically in Guatemala, Honduras, and El Salvador and receive interns from all over the world. In building these relationships, the center demonstrates the ways in which it is working to combat violence against women and acting as an example for other women's organizations.

\section{International Attention for Women's Movement}

The women's movement is largely responsible for bringing international attention to Nicaragua's humanitarian efforts. The women's movement participated in the Second World Conference on Human Rights in Vienna, Austria in 1993. This conference marked the beginning, "of a renewed effort to strengthen and further implement the body of human rights instruments that have been painstakingly constructed on the foundation of the Universal Declaration of Human Rights since 1948" (UN General Assembly 1993). The office of Special Rapporteur on Violence against Women was created during the Conference to promote and protect the rights of women, children, and indigenous peoples. The Special Rapporteur adopted a resolution in 1994 which condemned all acts of violence against women and girls and called for the elimination of all violence against women and girls. Most importantly, the resolution:

Emphasizes the duty of Governments to refrain from engaging in violence against women and to exercise due diligence to prevent, investigate and, in accordance 
with national legislation, punish acts of violence against women and to take appropriate and effective action concerning acts of violence against women, whether those acts are perpetrated by the State, by private persons or by armed groups or warring factions, and to provide access to just and effective remedies and specialized, including medical, assistance to victims (UNHCHR Online).

Feminist and women's organizations from the Nicaraguan women's movement also attended the 1994 International Conference on Population and Development in Cairo, Egypt. The Conference recognized that women are overburdened with work, their health, their families, and a lack of political influence (POPIN 1994). The Conference demanded that governments incorporate women into public policy-making in order to positively impact the status of women. More specifically, the Conference recognized that more than one third of women still do not have access to basic education. In 1995, Nicaraguan women's organizations attended the Fourth World Conference on Women in Beijing, China as well as the Worldwide Summit on Social Development in Copenhagen, Denmark. Both conferences reaffirmed what the previous conferences had proclaimed to be issues governments should be working towards to empower women. Currently, these women's organizations continue to work with international organizations and other nongovernmental organizations to establish a presence in the international arena. In addition, attending these prestigious conferences demonstrates to the Nicaraguan government and Nicaraguan people that their demands must be met and they will not stop until all women are equal, protected, and empowered. Fortunately, Ms. Mendoza stated that a lot of women have gained consciousness from the women's organizations and 
women's movement. She stated that NGOs are the ones providing women the ability to develop a political conscious. She attributes the rise in the status of women to the women's organizations. Ms. Mendoza believes that if a state is ever to advance or become democratized, it must include the voice of its women. In addition, she stated that the government has an obligation to fulfill their mandate. She stated, "We don't identify with a party. These issues don't belong to a party. We just have to keep going unified" (Author's interview, November 15, 2011).

Jirón asserts that women suffer from sexual abuse and violence, which stem from the patriarchal structure of the society. Her organization works to "build the women up" and they do so by strengthening women's bodies and minds. She pointed out that not only do women suffer, but that the abuse is intrafamilial. She stated that women's organizations had to construct laws that guarantee the rights of a woman, not laws that promise the rights of a woman. She stated that there must be more education on these subject matters and not for just women specifically. She stated that the progress being made for women is through a "bottom-up approach"- women's organizations are working from the ground up to effectively change Nicaraguan society. However, Mr. Arenas believes that the women's movement is the most independent and active social movement in Nicaragua. He pointed out that this may have changed four years ago, because of the repression and persecution the organizations and their members face from the government. He stated, “The women's movement has been a leading force in mobilizing the society. They realized that the future of democracy in Nicaragua is tied to the women's movement and women's rights" (Author's interview, November 1, 2011). 
Although there is some debate on level of success the women's movement and NGOs have achieved in pressuring the state to formulate and implement policies beneficial to women, the literature and interviews provide evidence supporting Hypothesis 2. The existence of the women's movement has had an impact on state policies.

Traditional Elements Push back against the Advancement of Women's Rights

\section{Catholic Church}

Zalaquett believes that the Church is the most dangerous threat to the center's goal. The Church reinforces a patriarchal society which affects the legal system, a system in which women's organizations find it difficult to seek justice. The center promotes changing the authoritarian society as a whole, not just between a man and a woman, the Church and the State. They emphasize changing all authoritarian relationships, including those between son and father and blacks and whites. Ms. Jimenez echoes the sentiments of Ms. Zalaquett. She pointed out that the Catholic Church's fundamentalist discourse tends to be manipulative in its message to women to adhere to its conservative agenda. Daniel Ortega's relationship with the Church changed significantly when, in 2006, his administration banned abortion, a move the Church was happy to support. Thus, public opinion about the women's movement is often ambivalent. Mr. Arenas pointed out that the Catholic Church has pushed for the criminalization of abortion. Feminists have denounced the Catholic Church and the government for decreasing the amount of effective democratic governance. Because of this, feminists have suffered political persecution. 
According to Ms. Viquez from CISAS, no one is able to influence the current administration because they have closed the spaces for participation. She stated that there is dialogue and coordination, but that it is clandestine. She cited the historical relationship between the Church and state and believes the Church has permeated the mentality of the government, forcing it to become more conservative. The government now practices what she referred to as, "Mas papita de El Papa" which essentially means the government practices stricter forms of patriarchy than the largest patriarchal institution worldwide (Author's interview, November 21, 2011). She stated that the government in this sense has become more fundamental than the Church hierarchy in Nicaragua.

\section{The Election of 1990}

In the mid-1980s, Nicaragua was in an economic crisis. Joseph Ricciardi explains that Nicaragua faced, "an accumulated excess demand for inflationary finance that was predominantly, but not solely, the consequence of deficit spending on the contra war" (Metoyer, 2000:36). The Sandinistas had inherited debt from the Somoza dynasty and funds were mismanaged. In addition, the economic crisis worsened with the civil war. Public programs, which benefited women for the most part, were suspended, and allocated to the defense budget (Metoyer, 2000:36). The Sandinistas struggled as they attempted to revitalize their country, which had been traumatized by the Somoza dynasty. However, as the election in 1990 drew closer, it was obvious they had not been able to implement change the Nicaraguan people needed.

Violeta Chamorro was virtually unknown to most Nicaraguans. For nine months, she was a part of the first Sandinista-led government junta, Junta Gobierno de 
Reconstrucción Nacional (JGRN) (Metoyer, 2000:41). The party had formed to address the direction of Nicaragua's future after the Revolution in 1979. Chamorro was a part of the nonrevolutionaries that had assisted to overthrow Somoza. Chamorro, after resigning from JGRN, ran La Prensa, a family-owned newspaper that preached anti-Sandinista rhetoric. Chamorro became a US favorite to run for President as a part of the Unión Nacional Opositora (UNO), a far right party that received support from the US State Department. Chamorro's campaign portrayed her as a non-political woman, who was devoted to her four children. In addition, Chamorro was a widow whose husband was a respected journalist who had been assassinated by the Somoza regime. She was always dressed in white, "to reflect purity from involvement in the war that was tearing apart the country" (Metoyer, 2000:43). She was often photographed with Cardinal Miguel Obando y Bravo, which depicted her as peace-loving and a favorite of the Catholic Church. She was non-controversial and rarely spoke, preferring male political officials to speak for her (Metoyer, 2000: 43). Ironically, two of Chamorro's children were Sandinistas, while the other two were strongly against the Sandinistas. However, Chamorro was a supermadre, or super mother, who was able to bring her divided children to the dinner table. According to Metoyer, Chamorro's campaign had four basic objectives:

1. To replace military authority with civil authority by restructuring the Ejército Popular Sandinista (ESP), (Sandinista Popular Army) to deprive it of its partisan character and ending the controversial draft, 2 . To stabilize the country by demobilizing contras and reducing the army, 3 . To restructure the economy by shifting toward a full market economy that relied on privatization, drastic 
cutbacks in state spending, and a credible promise to end the US embargo and, 4. To partially return confiscated land, even if the previous owners had been Somoza supporters, and pledge to convert all titles issued under the land reform to outright ownership of individual parcels (2000:44).

\section{Violeta Chamorro and the Feminist Movement}

Chamorro's platform did not promote the women's movement nor did it support any pro-women policies. Chamorro stated, "I am not a feminist, nor do I wish to be one" (Metoyer, 2000: 46). However, Chamorro promised to bring back the "nuclear family,"

which appealed to many women. The nuclear family represented the hope that peace and tranquility could be restored to war-torn families, implying of course that there had ever been peace. However, for many, the nuclear family did not exist and had not for quite some time (Metoyer, 2000:45). Chamorro's notion to bring back this extinct idea of what a family was demonstrated her lack of support for the women's movement. The feminist movement understood the process of industrial capitalism and the impact it would have on relations between men and women. "This development process relied on widening the separation of domestic and wage labor, which eventually led to the casting of women as domestic beings and men as economic providers" (Metoyer, 2000:45). Women would become more dependent on men and would solely be relied on for reproducing and homecare. The constant reference to the nuclear family demonstrated that the Chamorro campaign adhered to strict gender definitions. In addition, it demonstrated that they did not value the contributions of women, economically, politically, and socially, despite the fact that before, during, and after the revolution women had demonstrated their 
capabilities without the help of men. Her campaign and eventual presidency were symbolically important. She demonstrated that women and girls can earn high positions and be responsible for important government functions. Nevertheless, her campaign continued to promote a conservative ideology that women are meant to be housewives and loyal to their husbands. "In the end, Chamorro's stereotypical portrayal of women and motherhood reinforced rather than challenged the politics of gender in Nicaragua" (Metoyer, 2000:47).

\section{Violeta Chamorro's Neoliberal Reforms}

In the popular view, Chamorro had become a beacon for peace and stability. In 1988, the Sandinistas had implemented a second stabilization plan that resulted in a decrease in the standard of living (Metoyer, 2000:48). Women suffered the most as a result of this plan, forming one of the many reasons more women than men voted for Chamorro. Chamorro continued to work with the Sandinistas, much to the dismay of her ultra-conservative party members. Her cabinet was credited with ending the war in July 1990 and cutting defense personnel. In addition, she stabilized the córdoba, but did so with foreign aid. Furthermore, she reduced funding for public programs, privatized state enterprises and was responsible for massive layoffs (Metoyer, 2000:52). The Chamorro government believed that, "resource reallocation to the more productive sectors of the economy and changes in ineffective economic structures were inevitable remedies to market deficiencies and persistent economic lags" (Metoyer, 2000:56). However, this had a significant impact on women. Those who are critical of adjustment policies point out that the results of adjustment measures are evaluated in the paid labor market. Thus, 
women, many of whom labor at home or in the informal economy, are effectively left out and ignored in the evaluation of such policies. Women's work is essentially not worth evaluating and is justified by economists because it is unpaid and, "therefore has no repercussions for the macroeconomic variables with which adjustment programs are concerned" (Metoyer, 2000:56). Social services are cut and women are dealt the brunt of household labor and responsibilities. For example, in order to make hospitals more efficient, the state mandates that hospitals discharge patients earlier. Thus, the patient is sent home, where the burden of caring for that patient is transferred from the paid hospital worker to the unpaid female relative.

Stabilization programs are not guaranteed to finance long-term structural adjustment and structural adjustment is not guaranteed to stabilize a country's economy in the long term. Feminists argue that resource allocation is useless when evaluating the household because household work is unpaid. Feminists also argue that "extra burdens placed on households to absorb the costs of restructuring lead to absolute declines in living standards, including malnutrition" (Metoyer, 2000:65). "Women work longer hours than men in nearly all countries of the world, receive less education, have fewer economic resources, and have less access to political decision-making” (Benería, 1982:65). Traditionally, women are responsible for household maintenance. The sacrifices women make to maintain the household are invisible to structural adjustment policies, "which depend on households to absorb the cost of restructuring" (Metoyer, 2000:65). According to Metoyer, unemployment, hunger, and malnutrition rates rose between 1991-1996 (2000:64). Social services dwindled and more than half of the 
population was below the extreme poverty line. Succeeding UNO administrations continued the neoliberal policies initiated by Chamorro. The fact that the HDI did not drop during this time period can be traced to the work of NGOs who managed to provide services to the community (see below).

\section{Machismo}

As previously mentioned, machismo is, "tied into the cultural trait of the Latin American male's pursuit of importance, prestige, dignity, honor and status. Machismo has manifested itself nationally in male dominance in areas of politics and economics with women playing the more traditional roles associated with spirituality, motherhood and child rearing" (Staten, 2010:127). Machismo has led to "irresponsible paternity" because men feel compelled to prove their virility to other men by fathering as many children as they can (Collinson, 1990:9). Men leave the women who bear their children and abandon any family they may have begun. Women who live in rural areas often suffer more because they are isolated from other women and families. If they decide to stick around, this can sometimes prove more harmful for women. According to Comandante Carlos Nunex:

Machismo means reducing the woman to an object. The man acts as head of the family, directs everything, takes command, imposes his will without taking into account what I would call the exercise of democracy in the home (Collinon, 1990:9). 
There have been debates surrounding the cause of or root of machismo. Men sometimes blame women for perpetuating their position in society. Mothers are often blamed for not teaching their young boys what a machista mentality is and how to not grow up believing women are inferior. Mothers are also scorned for enabling their young boys, and for imposing assigned gender roles to their girls and boys. However, feminists point out that women have been taught for 1,000s of years that they are subordinate to men which is an inherent part of being a woman. Some feminists argue that women should not be held responsible for their own repression, that women are merely victims of this unjust societal pattern. However, men are often portrayed as victims of machismo as well. Men are expected to live up to societal expectations that they must be virile, be the sole provider, and act as the almighty head of household. Men are taught to be tough and are told they may not show affection or love for their women.

Presently, women's organizations are addressing machismo and attempting to rehabilitate men and women who are victims of this deeply engrained practice of society. Ms. Espino believes the Center for Violence Prevention is working to prevent this violence effectively because the center works on the relationship between men and women. The center focuses their work on portraying men as victims of machismo as well (Author's interview, November 18, 2011). The center wants to construct democratic families based in love, communication, and respect. Women's liberation has led many men to feel social anxiety because women are demanding equal rights in the workplace and questioning societal gender roles (Collinson, 1990:13). However, many men, according to Collinson, feel much less machista thanks to the Revolution and the 
women's movement (1990:13). Men can now expect to share household responsibilities or share the workplace. The Center for Violence Prevention specifically focuses on targeting school-age boys to prevent machismo from infiltrating their lives. The Center believes that if it can teach children from a young age the effects of machismo and what gender is and how it affects their lives, then there will be less of a need to rehabilitate families later.

\section{Domestic Violence}

However, most of the people I interviewed believe machismo is still prevalent in Nicaraguan society. Mr. Carroll for the US Embassy stated that the biggest obstacle Nicaraguan women face as a whole is the prevalence of machismo in Nicaraguan society. He believes that it is deeply embedded in Nicaraguan culture and is the root cause for the majority of domestic violence cases. Women's organizations recognize that machismo is one of the many reasons why domestic abuse is so common in Nicaragua. Ms. Espino believes that the greatest obstacle women face in Nicaragua is domestic violence. This violence manifests itself psychologically, physically, emotionally, sexually, racially, and between partners and amongst different genders. She believes in order to continue their work and to advance their objectives, the government must allow women more political space and respect women "from the womb" (Author's interview, November 18, 2011). If women are not guaranteed this right, the state and society as a whole, are accomplices to these abuses. Furthermore, Ms. Espino's states that mentalities, more than politics, need to change. Women need to stop being looked at as sexual objects and procreators. Ms. Vanegas believes that if the center had a radio program, they would be able to discuss 
issues of masculinity and prevention with a broader, perhaps younger audience. She believes the most important necessity for feminists is to keep working for the rights of women. As women and men gain political consciousness, violence will decrease, sexual abuse will decrease, and they will be able to implement more effective policies. In order for women and men to gain political consciousness, however, the government must enforce the policies that are already in place. In addition, the government should promote education about masculinity in order to transform machismo in Nicaraguan society.

Ms. Espino believes the center has prevented violence between families, schools and the community. Despite adversaries, it has organized the community and made the community more secure. In addition, the youth are more empowered and sensitive to the subjects of machismo and of arms and drug trafficking. Young people, on an individual level, have better self-esteems and are able to communicate more effectively. These organizations are working to eradicate violence against women by providing numerous services to women. As previously mentioned, women's organizations offer psychological, gynecological, and all other forms of health services. In addition, some of the women's organizations I interviewed offer couples counseling specifically for families suffering from domestic violence.

Although these organizations are addressing the causes and solutions for eradicating domestic violence and abuse, the current administration is not being held accountable for bringing justice to individuals who are responsible for invoking violence. Numerous cases each year are thrown out of the courts because of corruption. According to the representatives I interviewed, the dismissal of these cases demonstrates to the 
victims of these cases, the overwhelmingly majority of who are women, that they are powerless. Ms. Mendoza informed me that the biggest issue facing Nicaraguan women is violence. This organization works primarily in districts six and seven in Managua, the districts most plagued with cases of domestic violence. She stated that the Nicaraguan government offers women little opportunity for redress of grievances. Unfortunately, in cases where women come forward to seek justice for their case, they are often rejected and the case is "dumped". However, the collective diligently continues their work and documents case after case. It is extremely difficult for a person to come forth and admit she was a victim of abuse, especially, in cases where the abuser was a family member. These women should be revered for bringing the perpetrator to court so that he should not be able to inflict harm upon another person and should be seen as fulfilling one's civic duty. Yet, repeatedly, women are shown that if they bring these cases to court, they not only will face ridicule from family members, pestering from the media, and possible exclusion from their families, friends or co-workers, but that they will also be dismissed by the legal system that is put in place to protect them. The message the current administration is sending to women is a dangerous message to send to those who are attempting to keep society safer. It is also dangerous for a government and society that claim to be democratic, yet do not take into consideration half of their population because of their gender. Ms. Dominguez stated that there are three basic matters that affect Nicaraguan women, which are disrespect for women's human rights, the economy, and patriarchal institutions. She pointed out that there are laws to protect women from these three adversities, but the government doesn't always adhere to them. She cited the Law on Equal Rights and Opportunities which was passed in order to, "put more women in 
political posts, keep girls from marrying too young and protect women's rights in divorce cases" (UNCEDW Online). Regrettably, the law is often violated. According to Ms. Dominguez, women are not the priority. Fortunately, the Redes have an excellent relationship with the media and are always advertising the Redes' agenda.

The present study verifies that although the women's movement is able to influence state policies there are ebbs, flows and cross-currents. Traditional elements of society are also working to maintain traditional gender roles, supporting Hypothesis 3. However, by and large the women's organization has been able to preserve.

Status of Women in 1980 at the Beginning of the Revolution

The Somoza regime collapsed in 1979, heralding the beginning of the Nicaraguan Revolution. However, the research data used here to determine if the status of women has been affected by NGOs is taken from the year 1980 onward. This study begins in this year because data was not available any earlier from the United Nations Development Program (UNDP) in their Human Development Index Report. The United Nations' data begins in 1980 and continues until 2010. Although it would have been preferable to compare and contrast the status of women before 1980, we are restricted by the availability of data. However, after the fall of the Somoza regime, conditions within Nicaragua remained the same for quite some time because of the slow progress of the Revolution.

According to Table 1, the life expectancy at birth in Nicaragua was 58.5 in 1980. The mean years of schooling in 1980 were 3.2. The HDI value was 0.457 and, 
considering that the highest rating a country can receive is a 1.00 , this is a relatively low score. The GNI per capita was $\$ 2,596$.

Table 1: HDI Trends in Nicaragua from 1980-2010

\begin{tabular}{|l|l|l|l|l|}
\hline Years & $\begin{array}{l}\text { Life } \\
\text { expectancy } \\
\text { at birth }\end{array}$ & $\begin{array}{l}\text { Expected } \\
\text { years of } \\
\text { schooling }\end{array}$ & $\begin{array}{l}\text { GNI per } \\
\text { capita } \\
\text { (PPP } \\
\text { US\$) }\end{array}$ & HDI value \\
\hline 1980 & 58.5 & 7.9 & 2,596 & 0.457 \\
\hline 1985 & 60.7 & 7.4 & 2,290 & 0.463 \\
\hline 1990 & 64.1 & 7.6 & 1,832 & 0.473 \\
\hline 1995 & 67.3 & 8.8 & 1,608 & 0.495 \\
\hline 2000 & 69.6 & 9.8 & 2,010 & 0.533 \\
\hline 2005 & 71.9 & 10.8 & 2,250 & 0.566 \\
\hline 2010 & 73.8 & 10.8 & 2,378 & 0.587 \\
& & & & \\
\hline
\end{tabular}

Source: United Nations Development Programme, http://hdr.undp.org/en/statistics/hdi/.

Status of Women from 1990s-2000s

According to Table 1, there was a significant increase in Nicaragua's HDI from 1990-1995. The HDI jumped from 0.473 in 1990 to 0.495 in 1995. In 1980, the HDI had been 0.457 and from 1985 to 1990 , the HDI increased only 0.10 whereas in the 1990 s, the period where most women's organizations began to form, the HDI increased 0.22 points. In addition, life expectancy at birth increased from 64.1 in 1990 to 67.3 in 1995. Furthermore, the expected years of schooling grew from 7.6 in 1990 to 8.8 in 1995 . From 1995-2000 the HDI continued to grow from 0.495 in 1995 to 0.533 in 2000 . We can also see that there was a significant increase in the life expectancy at birth from 67.3 in 1995 to 69.6 in 2000. Lastly, there was an increase in the expected years of schooling, from 8.8 
in 1995 to 9.8 in 2000. Perhaps it is most important to note the substantial decline in GNI per capita. Table 1 demonstrates that in 1980 , the GNI per capita was $\$ 2,596$. In 1985 , the GNI per capita was $\$ 2,290$ and then drastically dropped in 1990 to $\$ 1,832$. It continued to drop from 1990 to 1995 and in 1995 the GNI per capita was $\$ 1,608$. Jimenez specified that women's organizations have been the only ones demanding the rights of women be recognized and respected. She stated that the advancement of women has come from the women's organizations, whose representatives have often suffered criminalization. In the 1990s, she stated, "Women's organizations advanced because we had the spirit of 'we want to advance'. It (the demand for an autonomous women's movement) definitely came from the women who demanded 'we need these organizations"” (Author's interview, November 17, 2011).

Status of Women: An Overview

As Table 1 demonstrates, the quality of life improved significantly from 19901995. The life expectancy at birth rose from 58.5 in 1980 to 60.7 in 1985. It increased in the years from 1985 to 1995 as well, as these non-governmental organizations continued to implement policies affecting the quality of life. The Human Development Index rose as well, although only slightly. In 1980, it was 0.440 and in 1995, the years for most policies introduced with the assistance of AMNLAE and FSLN and, despite the United States' embargo, it rose to 0.473 .

Table 1 demonstrates that the HDI has steadily increased since 1980.

Furthermore, the GNI per capita decreased significantly from 1985-1990 and continued to decrease in the 1990s. These decreases can be attributed to the inflationary finances 
that the Sandinistas incurred as a result of the Contra War. In addition, the Sandinistas had implemented a second stabilization plan that resulted in a decrease in the standard of living. Public programs were suspended and allocated to the defense budget (Metoyer 2000:36). The 1990s continued to be detrimental for Nicaraguan women as Chamorro implemented neoliberal policies. Metoyer explains that neoliberal policies favor resource reallocation to the more productive sectors of the economy in order to change unproductive economic structures, which leads to market shortages (2000:56).

Neoliberal policies affect mostly women. Women, who work primarily in the informal economy, are effectively left out and ignored in the evaluation of such policies. Women's work is essentially not worth evaluating, an attitude which is justified by economists because it is unpaid and, "therefore has no repercussions for the macroeconomic variables with which adjustment programs are concerned" (Metoyer 2000:56). Social services are cut under neoliberalism, while women are still left with the burden of household labor and responsibilities. However, the research presented in this study demonstrated that there are several health, education, and employment services available to women. These services are provided by the diligent work of women's NGOs whose shared objective is to ensure that women are treated with respect and afforded the same opportunities as men.

The decrease of GNI per capita can be attributed to the inadequate policies implemented by the Nicaraguan government. The likely explanation of HDI growth during the period of economic contraction is the efforts of NGOs to boost the quality of life for Nicaraguan women. Women's NGOs, such as the ones mentioned in this study, 
have continuously pushed policies through the Nicaraguan government to ensure that women are protected. Archival research demonstrated that women's NGOs introduced policies regarding women's health, legal, education, and employment benefits through effective lobbying. In addition, archival research demonstrated that women's NGOs have demanded accountability from the Nicaraguan government since the creation of AMNLAE. As evidenced in the interviews and surveys gathered for this study, the women's movement continues to face opposition from the Nicaraguan government. Much of the resistance that the women's movement has had to deal with stems from its continued to demands for accountability of the Nicaraguan government.

Women's NGOs offer health clinics, psychological services, legal counseling, employment opportunities, and educational seminars. The independent availability of these services offers a solid support network to women. Nicaragua's HDI continued to increase during the years when there were no resources for social support forthcoming from the government, indicating the effectiveness of NGOs in changing national quality of life. In addition, women's NGOs have led the way in changing Nicaraguan attitudes. Domestic abuse prevention services and educational programs are steadily changing the way Nicaraguans think about gender roles. Machismo, which has pervaded Nicaraguan society for decades, is slowly deteriorating. Women's NGOs have continued to grant men and women the opportunity to become politically conscious of the role they each play in Nicaraguan society. 
Thus, my examination of information has provided evidence supporting Hypothesis 4 stating that the women's movement and NGOs have proven beneficial in improving the welfare of women.

\section{Chapter Summary}

This chapter demonstrates the influence of women's NGOs on Nicaraguan society and the positive impact these NGOs have had on the status of women. In addition, it provides a historical background on the progress the women's movement has made in transforming governmental policies. It also provides examples of external factors that have influenced Nicaraguan society so that traditional gender roles are maintained. I also provide the HDI from 1980-2010 to demonstrate that the HDI has increased although several factors have affected this measure including structural adjustment programs which cut social program spending that benefited mostly women. This positive increase is attributed to the work of women's NGOs.

This chapter provides evidence and case studies from interviews that were conducted in Managua, Nicaragua with representatives from women's NGOs. In addition, surveys for this study demonstrate supporting evidence for the interviews as well. We observe the results of the interviews, surveys and the archival research to discover that the women's NGOs have impacted the status of women by offering numerous services specifically for women and implementing state policies that benefit women. 


\section{CHAPTER V: CONCLUSION}

The Nicaraguan Revolution of 1979 , led by the Sandinista Front for National Liberation (FSLN), provided a platform for women to develop their own women's rights organizations and to gain political leverage. Women led troops into combat, visited political prisoners, and organized shipments of food and ammunition. The participation of women led to the creation of a women's revolutionary party, the Luisa Amanda Espinosa Association of Nicaragua Women (AMNLAE). Unfortunately, women were largely absent from political decision making positions. Feminism was not prevalent during the Sandinista period. However, the Sandinistas were able to improve the education and health benefits of women as well as give them space to mobilize politically (Collinson, 1990).

Although the FSLN attempted to improve women's conditions, problems persisted. Violence against women was a serious problem, yet never openly discussed. Women were extremely vulnerable to sexual abuse. Gays and lesbians were largely ignored and condemned. Half the population was illiterate and the infant mortality was 130 per 1,000 live births (Jayko, 1982). Women living in urban areas had to raise families mostly on their own due to the majority of men being employed in the agricultural sector (Collinson, 1990). Somocista landowners required seasonal migrant workers to move around in order to maintain a cash crop economy. Many men would acquire a seasonal migrant job, stay there for four months, impregnate a woman, move, and then impregnate a different woman in a another part of the country (Collinson, 1990:9). This led to the "lack of a stable monogamous family life" (Collinson, 1990: 9). 
The Luisa Amanda Espinosa Association of Nicaragua Women (AMNLAE) created the Proclama, which established AMNLAE's priorities, addressed women's struggles within the revolution, and condemned machismo. "Most importantly, it argued that women's issues could not be 'put off' till after the war" (Collinson, 1990:145). It made it abundantly clear that women's issues were no longer concerns of only women and acknowledged that women were instrumental to the development of society. Towards the late 1980 s, AMNLAE began to act pragmatically and cater to the needs of women (Collinson, 1990). They opened training centers for women where they offered sex education, political training courses, as well as domestic training courses (Perkins, 1995). However, AMNLAE lacked ideological and organizational autonomy. In September 1988, AMNLAE changed its name to the Movement of Nicaraguan Women (Collinson, 1990). The organization planned to become more democratic and instituted an electoral process. However, elections were postponed, demonstrating yet again the lack of cohesion and efficiency present in this organization.

Although AMNLAE faced several obstacles in establishing an agenda for the women's movement that was autonomous from the FSLN, it was effective in passing legislation through the Nicaraguan government. AMNLAE was concerned with equal pay in the work place, family life, and political rights. The organization implemented the Law Regulating Relations Between Mothers, Fathers, and Children, in 1981, which created equal rights over children for both parents (Collinson 1990). In 1988, another law was passed that, "enabled marriage to be dissolved by mutual consent or by the will of either party" (Collinson 1990:114). Before the revolution, women, the elderly and the disabled 
were often left out of policy making. After diligent lobbying by AMNLAE, state pensions were made available for the elderly, disabled and widows of war. AMNLAE successfully fought for government funding for and expansion of child care centers and local nurseries.

The Luisa Amanda Espinosa Association of Nicaragua Women (AMNLAE) was able to pass a statute stating that women were to be guaranteed equal rights in the workplace. They assisted in ratifying the Constitution in 1986 which, "established an eight-hour working day and paid maternity leave" (Collinson, 1990:29). In addition, AMNLAE proposed the Agrarian Reform and Co-operative laws instituted in 1981. These were the first laws to, “recognize women's equal rights with men in relation to wages, access to land, and cooperative organization" (Collinson, 1990:41). These laws also defined women as, "co-operative members and landowners in their own right, regardless of whether or not they were heads of households or had adult male children to reap the benefits of agrarian reform" (Collinson, 1990:41). Most importantly, the 1987 Constitution laid the legal foundation for preventing violence against women. Article 36 condemns violence against women, and, "guarantees every citizen the right to physical, psychological, and moral integrity; it states that cruel, inhuman or degrading behavior is a crime punishable by law" (Collinson 1990:17).

Women in the feminist movement began to voice their concerns over the little progress the FSLN had made in ensuring equality for women. The FSLN was primarily concerned with the needs of the revolutionary party and its members regardless of their sex. It was the organization's original purpose to incorporate women into general 
revolutionary tasks. Thus, women demanded that their opinions and needs be taken into consideration. However, women became more disillusioned with the revolutionary parties. Women began to form their own women's organizations. These organizations initiated reforms in governmental policies, and helped change the way men think about women in Nicaraguan society (Disney, 2008). Through the actions of non-governmental organizations, Nicaraguan women have been able to participate in policy making, earn equal pay, and fight for their families and individual rights.

The Comité Nacional Feminista (CNF), or National Feminist Committee, was formed in January 1992 as a response from feminists who felt that the Movement of Nicaraguan Women did not serve the purpose of women (Stephen 1997:61). The Comité Nacional Feminista was comprised of several networks of women's organizations. The CNF was committed to fighting violence against women, and fighting all forms of oppression, including those on the basis of race, sex, ethnicity and age (Stephen, 1997:61). The women's movement fought for the approval of the Law 150 in 1992 which criminalizes sex crimes, corruption, prostitution, sex trafficking, and other crimes of this nature (Cuadra, 2010:15). The Nicaraguan government created the Commissary for Women and Children in 1995. The Commissary for Women and Children was created due to Law 228, a product of diligent lobbying on the part of the women's movement. In addition, the women's movement led the fight in 1996 to pass Law 230 which mandates the government to prevent domestic violence by providing resources to Nicaraguan citizens (Cuadra, 2010:15). 
However, they have had their work cut out for them. Spending for social programs that benefited mostly women suffered greatly from the 1980s to the 1990s. Social program spending decreased in the late 1980s due to the debt the Sandinistas incurred from the Somoza dynasty. Furthermore, structural adjustment programs in the 1990s severely cut social programs for women. However, the United Nations Development Programme's Human Development Index demonstrated that the quality of life for women improved significantly over this same period. From 1985 to 1990, the HDI rose from 0.463 to 0.473 . From $1990-1995$, the HDI rose 0.473 to 0.495 . The life expectancy at birth rose from 60.7 in 1985 to 64.1 in 1990. It continued to increase during the 1990s, as these non-governmental organizations continued to implement policies affecting the quality of life for women. The Human Development Index continued to rise, despite the United States' embargo, thanks in part to the government policies introduced with the assistance of AMNLAE and FSLN.

Perhaps the most effective form of measuring the work of the nongovernmental organizations comes from the data collected from the face-to-face interviews. Representatives from women's organizations unanimously agreed that women's organizations are responsible for the positive upswing of the status of women. It is evident that there were many obstacles that were present that should have led to the decrease in HDI. However, women's organizations, such as the ones listed in this study, contributed to the resources available to women including health clinics, legal services, and employment opportunities. In addition, the women's organizations have been extremely vocal in their quest for ensuring equality for all women. They are omnipresent 
and highly visible all over the country. From radio programs to demonstrations, the women's movement is the most autonomous and organized movement in Nicaragua. The women's movement has led the way in demanding universal human rights for all Nicaraguans. Furthermore, the women's movement has brought humanitarian issues to the forefront of international human rights campaigns.

However, these organizations continue to face many obstacles. Daniel Ortega's administration outlawed abortions in 2006. Since 2006, Ortega's administration and the Catholic Church have criminalized abortion. Women's organizations have become increasingly targeted as dissidents of the state as they continue to defend the right to choose. This backlash makes it increasingly difficult for these organizations to continue their work. Citizens feel as if there is no point in demanding justice from the legal system or state because they feel as if they are not being heard. Nevertheless, these organizations persist.

The data collected from the interviews and surveys demonstrated that domestic violence is the biggest issue Nicaraguan women face. Women's organizations such as CISAS and the March $8^{\text {th }}$ Women's Collective continuously rally against domestic violence. These organizations work within Nicaraguan communities to ensure that services are available to vulnerable populations. In addition, they offer educational services, educating community members on the effects of their actions. Organizations such as the Center for Prevention Against Violence works to educate children from a very young age on the damaging effects of machismo on men and women. Evidence suggests there has been a significant increase in the reporting of domestic violence. The evidence 
demonstrates that these organizations are effective in delivering the message of accountability and hope to Nicaraguans, especially women who are the majority of domestic violence abuses.

However, although these organizations continue to observe improvements in the daily life of women in Nicaragua, problems persist. The interviews demonstrated a need for accountability from the government. Several laws were established in the 1980s and 1990s to ensure equality for all Nicaraguans. Specifically, there were laws that granted women the right to respect, dignity, and equality. Yet women continue to struggle for these rights. Representatives from the organizations stated that although the laws are put in place to protect women, the laws are no good if the state does not respect them. Cases of domestic abuse or domestic violence are frequently thrown out or not acknowledged at all. The numbers are higher for women who have been assaulted by public or affluent figures. Nonetheless, these organizations continue to demand that the state take responsibility for these women. If not, they believe the state is complicit in the ongoing crimes against women.

Although there appears to be a minor lack of cohesion in the Nicaraguan feminist movement, my experience demonstrated that the women's movement is still very much alive, vibrant, and for the most part, working towards the same objectives. Each and every movement will suffer ideological differences. However, this movement specifically is very much a sisterhood of acceptance and equality. Not one representative spoke poorly about another representative or another organization's work. Instead, the women chose to refer to themselves as compañeras, and demonstrated their pride in the work 
they were accomplishing together. In addition, all of the representatives knew of the other representatives I was going to interview and offered kind words about the work they were doing. Furthermore, several representatives offered me names, telephone numbers, and addresses of other organizations I could use for my study. On one occasion, I was invited to a lecture that several organizations had organized for one of the universities. Several women representatives spoke on behalf of the movement and its objectives, yet were representatives from different organizations. This event demonstrated an effort to bring about in the women's movement in a cohesive message for the new generation of future feminists.

As the Ortega administration begins its new term unlawfully, the political space for women's organizations to organize effectively may become smaller. Thus, it is extremely important for these organizations to work together collectively to ensure that the movement continues its quest to ensure equal rights for all Nicaraguan people, especially women. I believe that is why organizations such as the March $8^{\text {th }}$ Women's Collective organized the event at the university. The organizations are continuously recruiting young people into the movement to continue to strengthen it. The organizations are effectively able to do this as well because they publicize their events on the radio, which is the largest form of communication where Nicaraguans receive their news. In addition, the women's movement continues to hold demonstrations and awareness campaigns.

As I previously stated in Chapter I, this study was significant for three reasons. First, this study demonstrated the effectiveness of women's NGOs. It is my hope that 
they will continue to receive further allocation financial and social resources so that they are able to continue with the work they are performing. Second, this study was concerned with the lack of research published on the women's movement. This study strove to add to the growing amount of research performed in Nicaragua and to demonstrate the effectiveness of NGOs in order for these organizations to continue to gain political leverage. Lastly, the purpose of this study was to bring notoriety to this vast and inspirational women's movement in the hopes it could be an example to other women's movements. Women's NGOs in Nicaragua have effectively networked with other NGOs and IGOs. Specifically, Nicaraguan feminists have been effective in building partnerships across borders to form alliances with other Central American women's NGOs. Nevertheless, this study desired to present the Nicaraguan women's movement as an example to all other women's movements worldwide, and I believe it did just that.

There is a famous saying in the Nicaraguan movement, "Nos tienen miedo porque no tenemos miedo" "They fear us because we have no fear." This statement summed up for me all that the Nicaraguan feminist movement embodies. They have been able to do all of the work they have done over multiple decades because they have no fear. They know that the work they are performing is a cause of the status of women improving. They have worked tirelessly to lobby for governmental policies, to offer services the government refused to provide, and to demand accountability and justice for all Nicaraguan people. Their efforts have not gone unnoticed. The United Nations and several IGOs and NGOs recognize the work of this movement and of the women who propel the movement forward. It is women such as the ones who were mentioned in this 
study that inspire others to join in and fight. I researched where the saying came from, and I discovered it has been used in other feminist movements in Latin America as well, including Colombia and Mexico, which demonstrates a Latin American feminist unity.

While in Nicaragua, I was given a song called, "Juntas, Todas Libres" by one of the organizations. There is no name of the organization that wrote it, no one mentioned which organizations used it primarily or when. I was only told that they sang it during demonstrations and marches. This insignificant detail spoke volumes to me and as I began to read the lyrics, I understood why. (Not translated to maintain message of song).

Soy una mujer normal, No me miras mal que yo soy libre

De andar de aqui pa' allá

Y de hacer todo lo que me pique.

Si vos te me arrimás,

Somos la grande mayoría.

Solo quiero igualdad.

Todas juntas, todas libres

Ya no más explotación,

Ya no quiero más de to violencia, nit u insistencia.

Cuando se ponga el sol,

Vamos a romper las diferencias, sin consecuencia.

Porque no hay nadie como yo,

Pero soy más junto a vos

Desenchufá la violencia y conectáte al amor.

Todas juntas, todos libres.

Libre de tu violencia, de tu maltrato de tu ironía.

Libre de esas noticias de pesadilla, todos los días.

Libres de VIH con alegria todas unidas

Libre la mayoría que ya se acerca la luz del dia.

Libre para ser la mujer que quiero ser.

Libre del acoso para caminar.

Libre de ignorancia y de la impunidad.

Todas juntas, todas libres.

Porque no hay nadie como yo

Pero soy más junto a vos

Desenchufá la violencia y conectáte al amor. 


\section{REFERENCES}

“1972: Earthquake wreaks devastation in Nicaragua." BBC News Online: On This Day. 23 Dec 2005.

http://news.bbc.co.uk/onthisday/hi/dates/stories/december/23/newsid_2540000/25 4004m.

Babb, Florence. Mapping Gender and Cultural Politics in Neoliberal Nicaragua. Austin: University of Texas, 2001.

Baltodano, Ana Maria Riguero. Las redes sociales en Nicaragua. Managua: Ediciones Restauración, 2010.

Bayard de Volo, Lorraine Bayard. Mothers of Heroes and Martyrs. Baltimore: The Johns Hopkins University Press, 2001.

Chant, Sylvia H, and Nikki Craske. Gender in Latin America. New Brunswick, N.J: Rutgers University Press, 2003.

Colburn, Forrest D. My Car in Managua. Austin: University of Texas Press, 1991.

Collinson, Helen, ed. Women and Revolution in Nicaragua. Feb 1990.

Craske, Nikki. Women and Politics in Latin America. New Brunswick, NJ: Rutgers University Press, 1999.

Disney, Jennifer Leigh. Women's Activism and Feminist Agency in Mozambique and Nicaragua. Philadelphia: Temple University Press, 2008.

Dore, Elizabeth, and Maxine Molyneux. Hidden Histories of Gender and the State in Latin America. Durham, NC: Duke University Press, 2000.

Ewig, Christina (1999). “The Strengths and Limits of the NGO Women's Movement Model: Shaping Nicaragua's Democratic Institutions.” Latin American Research Review, 34 (3), 75-102.

Foroohar, Manzar. The Catholic Church and Social Change in Nicaragua. Albany, New York: State University of New York Press, 1989.

Gobat, Michel. Confronting the American Dream: Nicaragua Under U.S. Imperial Rule. Durham: Duke University Press, 2005.

González-Rivera, Victoria, and Karen Kampwirth. Radical Women in Latin America: Left and Right. University Park: Pennsylvania State University Press, 2001. 
"Human Development Index: Equality matters if we are to reduce poverty."

Guardian.co.uk. 21 Nov 2010.

http://www.guardian.co.uk/globaldevelopment/datablog/2010/nov/04/human-

development-index-equality-matters

Jahan, Selim. 2002. "Measuring Living Standard and Poverty: Human Development Index as an Alternative Measure", Work Document presented in the Global Labor Standards and Living Wages Group Meeting. University of Massachusetts, April 19 and 20. http://www.peri.umass.edu/fileadmin/pdf/gls_conf/glw jahan.pdf

Jayko, Margaret, comp. Women and the Nicaraguan Revolution. New York: Pathfinder Press, 1982.

Kampwirth, Karen. Feminism and the Legacy of Revolution: Nicaragua, El Salvador, Chiapas. Ohio: Center for International Studies, 2004.

Kampwirth, Karen. Women \& Guerrilla Movements: Nicaragua, El Salvador, Chiapas, Cuba. University Park, Penn: Pennsylvania State University Press, 2002.

Landau, Saul. The Guerilla Wars of Central America. New York: St. Martins Press, 1993.

Linkogle, Stephanie. Gender, Practice, and Faith in Nicaragua. Vermont: Ashgate Publishing Company, 1996.

Lira, Elvira Cuadra and Martinez, Juana Jiménez. El movimiento de mujeres y la lucha por sus derechos en Nicaragua. Managua: CINCO, 2010.

Macdonald, Laura. Supporting Civil Society: The Political Role of Non-Governmental Organizations in Central America. New York, N.Y: St. Martin's Press, 1997.

Maier, Elizabeth, and Nathalie Lebon. Women's Activism in Latin America and the Caribbean: Engendering Social Justice, Democratizing Citizenship. New Brunswick, N.J: Rutgers University Press, 2010.

Mehl, Amanda. "Directory of Nicaraguan Women's Movements." Working Capital for Community Needs. 2003. 20 Nov 2010. http://wccnica.org/womens_organizations.html.

Méndez, Jennifer B. From the Revolution to the Maquiladoras: Gender, Labor, and Globalization in Nicaragua. Durham: Duke University Press, 2005.

Metoyer, Cynthia C. Women and the State in Post-Sandinista Nicaragua. Boulder: Lynne Rienner, 2000. 
Montenegro, Sophia. Los Medios de Comunicación como actors politicos en Nicaragua. CINCO: Managua, 2007.

Naples, Nancy A, and Manisha Desai. Women's Activism and Globalization: Linking Local Struggles and Transnational Politics. New York: Routledge, 2002.

"Nicaragua." One World Action. 22 Nov 2010. http://www.oneworldaction.org/our_partners/latin_america/nicaragua_partners

Perkins, Tyrion. "Community Movements in Nicaragua." Green Left. 13 Sep 1995. 20 Nov 2010. http://www.greenleft.org.au/node/10755.

Randall, Margaret. Gathering Rage: The Failure of Twentieth Century Revolutions to Develop a Feminist Agenda. New York, NY: Monthly Review Press, 1992.

Randall, Margaret. Sandino's Daughters Revisited. New Brunswick: Rutgers University Press, 1994.

Staten, Clifford. The History of Nicaragua. Santa Barbara: ABC-CLIO, 2010.

United Nations General Assembly. 1993. Vienna Declaration and Programme of Action, adopted by World Conference on Human Rights, Vienna, June, 14.-25, 1993, U.N. Doc. A/CONF.157/24

United Nations High Commission for Human Rights. (online) Special Rapporteur on violence against women, its causes and consequences. http://www.ohchr.org/EN/Issues/Women/SRWomen/Pages/SRWomenIndex.aspx

United Nations Population Information Network (POPIN), 1994. Report of the International Conference on Population and Development. A/Conf.171/13: Report of the ICPD (94/10/18).

Vilas, Carlos M. The Sandinista Revolution: National Liberation and Social Transformation in Central America. New York: Monthly Review Press, 1986.

Viquez, Ana Quiróz. Hambre Cero: Avances y Desafíos. IEEPP: Managua, 2011. 